\title{
Analytical validation of two RT-qPCR tests and detection of spring viremia of carp virus (SVCV) in persistently infected koi Cyprinus carpio
}

\author{
Sharon C. Clouthier ${ }^{1, *}$, Tamara Schroeder ${ }^{1}$, Emma K. Bueren $^{2,4}$, Eric D. Anderson ${ }^{3}$, \\ Eveline Emmenegger ${ }^{2}$ \\ ${ }^{1}$ Fisheries \& Oceans Canada, Freshwater Institute, Winnipeg, Manitoba R3T 2N6, Canada \\ ${ }^{2}$ US Geological Survey, Western Fisheries Research Center, Seattle, WA 98115, USA \\ ${ }^{3}$ Box 28, Group 30, RR2, Ste Anne, Manitoba R5H 1R2, Canada \\ ${ }^{4}$ Present address: Department of Biological Sciences, Virginia Polytechnic Institute and State University (Virginia Tech), \\ Blacksburg, VA 24061, USA
}

\begin{abstract}
Spring viremia of carp virus (SVCV) ia a carp sprivivirus and a member of the genus Sprivivirus within the family Rhabdoviridae. The virus is the etiological agent of spring viremia of carp, a disease of cyprinid species including koi Cyprinus carpio L. and notifiable to the World Organisation for Animal Health. The goal of this study was to explore hypotheses regarding intergenogroup (Ia to Id) SVCV infection dynamics in juvenile koi and contemporaneously create new reverse-transcription quantitative PCR (RT-qPCR) assays and validate their analytical sensitivity, specificity (ASp) and repeatability for diagnostic detection of SVCV. RT-qPCR diagnostic tests targeting the SVCV nucleoprotein (Q2N) or glycoprotein (Q1G) nucleotides were pan-specific for isolates typed to SVCV genogroups Ia to Id. The Q2N test had broader ASp than Q1G because Q1G did not detect SVCV isolate 20120450 and Q2N displayed occasional detection of pike fry sprivivirus isolate V76. Neither test cross-reacted with other rhabdoviruses, infectious pancreatic necrosis virus or co-localizing cyprinid herpesvirus 3. Both tests were sensitive with observed $50 \%$ limits of detection of 3 plasmid copies and high repeatability. Test analysis of koi immersed in SVCV showed that the virus could be detected for at least $167 \mathrm{~d}$ following exposure and that titer, prevalence, replicative rate and persistence in koi were correlated significantly with virus virulence. In this context, high virulence SVCV isolates were more prevalent, reached higher titers quicker and persisted in koi for longer periods of time relative to moderate and low virulence isolates.
\end{abstract}

KEY WORDS: SVCV · RT-qPCR · Analytical specificity · Analytical sensitivity · Persistent infection · Koi $\cdot$ Sprivivirus

\section{INTRODUCTION}

Spring viremia of carp virus (SVCV) belongs to the genus Sprivivirus within the family Rhabdoviridae in the order Mononegavirales (ICTV 2019). The disease spring viremia of carp (SVC) is notifiable to the World Organisation for Animal Health (OIE) (OIE

\footnotetext{
*Corresponding author: sharon.clouthier@dfo-mpo.gc.ca
}

2019a) and reportable to the Canadian Food Inspection Agency (CFIA 2019). The primary host for SVCV worldwide is common carp Cyprinus carpio L. (Fijan 1999), but natural outbreaks of the disease have occurred in other cyprinid fish species (Ahne et al. 2002). The host range might be broader than currently recognized, since cell lines from birds, reptiles 
and mammals support growth of SVCV (Bachmann \& Ahne 1974, Clark \& Soriano 1974). The discovery of SVCV in Chinese firebelly newts (Ip et al. 2016) extends the host range of the virus from fish to amphibians.

SVCV can be virulent in juvenile carp (70-100\% mortality) during their first year, and die offs are observed in the spring when the water temperature is between 10 and $17^{\circ} \mathrm{C}$ (Ahne et al. 2002). Mortality in older, mature fish is not common but can occur in populations that have never been exposed to the virus (Ahne et al. 2002, Dikkeboom et al. 2004). The dynamic of SVC is dependent on a number of factors including virus isolate, water temperature, host age and condition, population density and stress factors (Ahne et al. 2002). The gill is considered the primary portal of entry into the host, with subsequent viremia and dissemination of the endotheliotropic virus to the liver, kidney, spleen, heart and gastrointestinal tract (Ahne 1977, 1978). Like other fish rhabdoviruses, SVCV is also neurotropic (Wang et al. 2017), a feature that may allow the virus to exploit other entry routes into the host and establish a persistent type of infection in the brain (Sepahi et al. 2019). Virus is initially observed in kidney tissue followed by higher titers in liver and spleen tissue with concomitant decline in kidney titers (Faisal \& Ahne 1984). Little is known regarding the kinetics and titer of SVCV in brain tissue except that the titer is typically lower compared to kidney tissue (Wolf 1988).

Some strains of SVCV can persist in carp for more than $70 \mathrm{~d}$ (Ahne et al. 2002), but few (if any) studies have investigated inter-genogroup differences in persistence, a gap identified by the OIE SVCV reference laboratory (OIE 2019b). Horizontal transmission of the virus can occur from asymptomatic apparently healthy adult survivors (Bekesi \& Csontos 1985) that shed virus into the water through their excreta (Wolf 1988, Ahne et al. 2002) or via their reproductive products (Bekesi \& Csontos 1985). Wolf (1988) speculated that peak virus shedding may coincide with rising water temperatures and the annual spring spawning cycle resulting in inter-generational virus transmission.

Within the genus Sprivivirus, SVCV isolates are classified as members of the species Carp sprivivirus, whereas grass carp rhabdovirus (GrCRV), tench rhabdovirus (TenRV) and pike fry rhabdovirus (PFRV) isolates have been taxonomically classified to the species Pike fry sprivivirus (Stone et al. 2013). Carp spriviviruses have been grouped phylogenetically into 4 genogroups designated Ia to Id (Stone et al. 2003) and 2 subgroups of Ia (Iai and Iaii) (Miller et al.
2007). The genogroups correlate geographically with the area of isolation. Genogroup Ia isolates have been found in North America and China, whereas isolates of genogroups Ib to Id originate from central and eastern Europe. Virus isolation by cell culture is the most common method used for detection of SVCV and is recommended by the OIE for surveillance activities conducted to establish the SVCV-free status of susceptible fish populations (OIE 2019b). The test can detect all known SVCV genogroups, but 7-14 d are required to complete the assay (OIE 2019b).

A number of reverse-transcription quantitative PCR (RT-qPCR) assays have been developed for detection of SVCV and characterized with respect to their analytical performance (Liu et al. 2008, Yue et al. 2008, Zhang et al. 2009, Misk et al. 2016, 2017, Shao et al. 2016). The fitness of diagnostic tests for detection of SVCV can be validated to standards such as those proposed by the OIE (2019c) to ensure that their analytical and diagnostic performance is suitable for their intended purpose. A multi-phased study was designed to develop and validate 2 RTqPCR diagnostic tests targeting SVCV nucleoprotein (Q2N) or glycoprotein (Q1G) nucleotides. Here we show that the analytical performance of these tests makes them suitable candidates for assessing their diagnostic performance. In addition, we demonstrate the utility of the tests while investigating SVCV infection dynamics in koi and testing hypotheses related to virus virulence and persistence with isolates from genogroups Ia to Id. Specifically, we hypothesized that the tests could be used to measure virus fitness traits describing SVCV virulence.

\section{MATERIALS AND METHODS}

\subsection{Virus culture and nucleic acids}

\subsubsection{Viruses}

The viruses used in this study are described in Table 1. Spriviviruses of carp (i.e. SVCV) and pike fry (i.e. GrCRV, TenRV) were cultured at $20^{\circ} \mathrm{C}$ using epithelioma papulosum cyprini (EPC) cells, whereas infectious hematopoietic necrosis virus (IHNV) and viral hemorrhagic septicemia virus (VHSV) were cultured on the same cell line at $15^{\circ} \mathrm{C}$ (Fijan et al. 1983, Winton et al. 2010). Cyprinid herpesvirus 3 (CyHV-3) was cultured at $15^{\circ} \mathrm{C}$ on common carp brain cells (Neukirch et al. 1999), while infectious pancreatic necrosis virus (IPNV) was cultured at the same tem- 
Table 1. Virus isolates used in this study. Family, genus and species names accepted by the ICTV (2019) are italicized

\begin{tabular}{|c|c|c|c|}
\hline Virus & Genogroup & Year, origin & Description \\
\hline \multicolumn{4}{|c|}{ Alloherpesviridae, Cyprinivirus } \\
\hline \multicolumn{4}{|c|}{ Cyprinid herpesvirus 3 (CyHV-3) } \\
\hline $\mathrm{F} 98-50^{\mathrm{a}}$ & European lineage & 1999, USA & New York \\
\hline \multicolumn{4}{|c|}{ Birnaviridae, Aquabirnavirus } \\
\hline \multicolumn{4}{|c|}{ Infectious pancreatic necrosis virus (IPNV) } \\
\hline Canada $3^{\mathrm{b}}$ & $\mathrm{V}^{\mathrm{c}}$ & 1980, Canada & Arctic \\
\hline \multicolumn{4}{|c|}{ Rhabdoviridae, Sprivivirus } \\
\hline \multicolumn{4}{|c|}{ Carp sprivivirus, spring viremia of carp virus (SVCV) } \\
\hline UK970469 & Iai & 1997, UK & Asian import \\
\hline $980528^{\mathrm{d}}$ & Iai & 1998, UK & Asian import \\
\hline $980451^{\mathrm{d}}$ & Iai & 1998, UK & Asian import \\
\hline $\mathrm{D} 148^{\mathrm{e}}$ & Iai & 2001, UK & Asian import \\
\hline $\mathrm{D} 120^{\mathrm{e}}$ & Iai & 2001, UK & Asian import \\
\hline $\mathrm{E} 208^{\mathrm{e}}$ & Iaii & 2002, UK & \\
\hline $\mathrm{WI}^{\mathrm{f}}$ & Iai & 2002, USA & Wisconsin \\
\hline $\mathrm{NC} 2002^{\mathrm{g}}$ & Iaii & 2002, USA & $\begin{array}{l}\text { North Carolina; } \\
\text { in vivo study }\end{array}$ \\
\hline $\mathrm{IL}^{\mathrm{h}}$ & Iai & 2003, USA & Illinois \\
\hline $\mathrm{MO}^{\mathrm{h}}$ & Iaii & 2004, USA & Missouri \\
\hline $\mathrm{WA}^{\mathrm{h}}$ & Iaii & 2004, USA & Washington \\
\hline $20040741^{\mathrm{i}}$ & Ia & 2004, China & In vivo study \\
\hline HHOcarp06 $^{j}$ & Iai & 2006, Canada & Ontario \\
\hline $\mathrm{MS}^{\mathrm{k}}$ & Ia & 2007, USA & Wisconsin \\
\hline $20070165^{\mathrm{i}}$ & Ia & 2007, China & In vivo study \\
\hline $\mathrm{OH}^{\mathrm{k}}$ & Ia & 2008, USA & Ohio \\
\hline $20100910^{\mathrm{i}}$ & Ia & 2010, China & In vivo study \\
\hline $20120450^{\mathrm{i}}$ & Ia & 2012, China & In vivo study \\
\hline $202238^{p}$ & Ia & 2016, USA & Synthetic DNA \\
\hline $\mathrm{RHV}^{\mathrm{d}}$ & $\mathrm{Ib}$ & 1989, Ukraine & In vivo study \\
\hline E134 ${ }^{1}$ & $\mathrm{Ib}$ & 2002, UK & Asian import \\
\hline $\mathrm{P} 4-7^{\mathrm{d}}$ & Ic & 1983, Russia & In vivo study \\
\hline $\mathrm{N} 1-5^{\mathrm{d}}$ & Ic & 1986, Ukraine & \\
\hline 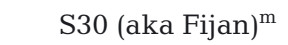 & Id & 1971, Yugoslavia & In vivo study \\
\hline$M 2-78^{d}$ & Id & 1983, Moldova & \\
\hline $\mathrm{N} 3-14^{\mathrm{d}}$ & Id & 1986, Ukraine & \\
\hline $880110^{1}$ & Id & 1988, UK & Asian import \\
\hline $880124^{1}$ & $\mathrm{Id}$ & 1988, UK & Asian import \\
\hline \multicolumn{4}{|c|}{ Pike fry sprivivirus, grass carp rhabdovirus (GrCRV) } \\
\hline V76 $6^{\mathrm{d}}$ & II & 1982, Germany & \\
\hline \multicolumn{4}{|c|}{ Pike fry sprivivirus, tench rhabdovirus (TenRV) } \\
\hline UK950237 & IV & 1995, UK & \\
\hline \multicolumn{4}{|c|}{ Rhabdoviridae, Novirhabdovirus } \\
\hline \multicolumn{4}{|c|}{ Hirame novirhabdovirus, hirame rhabdovirus } \\
\hline $\mathrm{CA}-9703^{\mathrm{q}}$ & & 1997, Korea & Synthetic DNA \\
\hline \multicolumn{4}{|c|}{ Piscine novirhabdovirus, viral hemorrhagic septicemia virus (VHSV) } \\
\hline $99-292^{\mathrm{n}}$ & IVa & 1999, Canada & British Columbia \\
\hline CA-NB00-0 $1^{\mathrm{n}}$ & $\mathrm{IVb}$ & 2000, Canada & New Brunswick \\
\hline \multicolumn{4}{|c|}{ Salmonid novirhabdovirus, infectious hematopoietic necrosis virus (IHNV) } \\
\hline $93-057^{\circ}$ & $\mathrm{U}$ & 1993, Canada & British Columbia \\
\hline \multicolumn{4}{|c|}{ Rhabdoviridae, Perhabdovirus } \\
\hline \multicolumn{4}{|c|}{ Unclassified, Micropterus salmoides rhabdovirus (MSRV) } \\
\hline $\mathrm{YHO}^{\mathrm{r}}$ & & 2017, China & Synthetic DNA \\
\hline \multicolumn{4}{|c|}{ 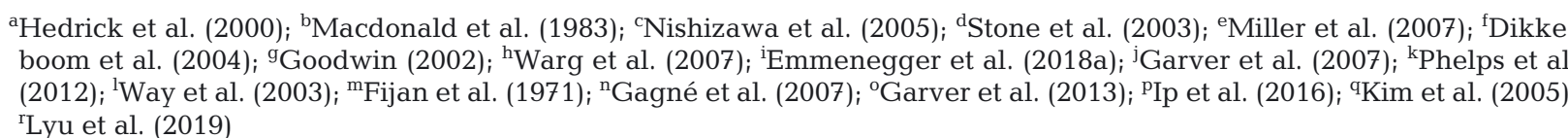 } \\
\hline
\end{tabular}


perature on chinook salmon embryo cells (Lannan et al. 1984). All cell lines were cultured using minimal essential medium containing Hanks' salts, $2 \mathrm{mM}$ L-glutamine and $2-10 \%$ fetal bovine serum (Life Technologies). Media preparations were supplemented with antibiotic/antimycotic (Life Technologies) following virus adsorption. Virus was prepared using 2 methods. The traditional virus preparations were generated by infecting cell monolayers at a multiplicity of infection (MOI) of 0.01 to 0.0001 and then harvesting monolayers when they exhibited complete cytopathic effect. These preparations were stored at $-80^{\circ} \mathrm{C}$ as whole cell lysates. For the enriched virus preparations, cells were inoculated with SVCV HHO carp06 at an MOI of 1.0 and then harvested within 24-72 $\mathrm{h}$ after infection when the virus was still associated with the cells. The cell culture supernatant was removed at harvest and RNA was extracted from the infected monolayer. Virus titers were estimated using the Spearman (1908) and Kärber (1931) endpoint dilution assay (i.e. $50 \%$ tissue culture infective dose $\left[\mathrm{TCID}_{50}\right]$ ) or by plaque assay (PA) (i.e. plaqueforming units [pfu]) (Batts \& Winton 1989).

\subsubsection{Viral nucleic acid}

Nucleic acid used in the analytical validation study (i.e. ASp) was extracted from traditional virus preparations of CyHV-3, SVCV, GrCRV, TenRV, VHSV, IHNV or IPNV. CYHV-3 DNA was prepared from infected whole-cell lysates as described by Clouthier et al. (2017). Viral RNA for cDNA synthesis was extracted using the QiaAmp Viral RNA Extraction Kit (Qiagen) after clarification $\left(2500 \times g, 10 \mathrm{~min}, 4^{\circ} \mathrm{C}\right)$ and centrifugation $\left(21100 \times g, 90 \mathrm{~min}, 4^{\circ} \mathrm{C}\right)$ of infected whole-cell lysates. The semi-purified viral RNA or DNA was quantified using the Nanodrop 8000 (Nanodrop Technologies) and then stored at $-80^{\circ} \mathrm{C}$. Reverse transcription was performed as described by Clouthier et al. (2017) except that $100 \mathrm{ng}$ of RNA were used as the template.

The enriched SVCV HHOcarp06 preparation was used as the source of RNA for creating P1 and P2 positive control samples for the Q1G and Q2N tests. TRI$\mathrm{zol}^{\mathrm{TM}}$ Reagent (ThermoFisher Scientific) was added directly to the infected monolayer in the cell culture flask immediately following removal of the cell culture medium. A cell suspension was made in the reagent by physically releasing the adherent monolayer using a cell scraper (ThermoFisher Scientific) and then homogenized with a steel bead $(5 \mathrm{~mm})$ and the TissueLyser (25 Hz, 2 min; Qiagen). RNA was extracted manually (ThermoFisher Scientific), resuspended in 50-200 $\mathrm{Hl}$ molecular-grade water, measured as described in the preceding paragraph and stored at $-80^{\circ} \mathrm{C}$. Synthesis of cDNA was performed with RNA 10 -fold serially diluted over 8 orders of magnitude (unless otherwise specified).

Tissue samples (virus free, SVCV NC2002-infected or with exogenous viral RNA from the enriched SVCV HHOcarp06 preparation) were used as the source of RNA for the RT-qPCR tests evaluated in the analytical validation study. The SVCV NC2002 exposure study with koi was described by Clouthier et al. (2021). Tissue samples were processed using TRI$\mathrm{zol}^{\mathrm{TM}}$ Reagent or TRI Reagent ${ }^{\mathrm{TM}}$ (ThermoFisher Scientific). Tissue homogenization and RNA extraction, quantitation and storage were performed as described in the preceding paragraph. Synthesis of cDNA was performed with 1500 ng genomic RNA (unless otherwise specified).

Homogenates of whole fish from the virus challenge study were prepared as described by Emmenegger et al. (2018a). The virus titer in each homogenate was evaluated using the PA test as described by Batts \& Winton (1989) and expressed as pfu g ${ }^{-1}$ tissue. Virus titers were also determined with RNA extracted from each homogenate using TRIzol $^{\mathrm{TM}}$ Reagent (ThermoFisher Scientific) and purified on Zymo-Spin columns as described by the manufacturers (Zymo Research). The RT reactions and Q2N qPCR assays were performed as described in this section and in Section 2.3. In this case, virus titer was expressed as equivalent plasmid copies (epc) $\mathrm{g}^{-1}$ tissue.

\subsubsection{Plasmids}

DNA encoding the full-length nucleoprotein or glycoprotein gene from SVCV 202238, hirame rhabdovirus (HIRRV) CA-9703 and Micropterus salmoides rhabdovirus (MSRV) YH01 was synthesized and inserted in the vector pJ204 (ATUM) (Table 1).

Artificial positive control (APC) plasmids (ATUM) pSVCV-APC-Q1G (2874 bp) for the Q1G test and pSVCV-APC-Q2N (2878 bp) for the Q2N test were designed using the same approach as described by Clouthier et al. (2015) (see Fig. S1 in the Supplement at www.int-res.com/articles/suppl/d143p169_supp. pdf). Linearized plasmid DNA was prepared as described by Clouthier et al. (2017), except that the restriction enzyme $\mathrm{NCOI}$ (New England Biolabs) was used to cut the DNA. The purified DNA was diluted and used as P3A and P3B positive control samples for 
the Q1G or Q2N tests. The plasmids each correspond to an estimated $1.87 \times 10^{6} \mathrm{~g} \mathrm{~mol}^{-1}$ and $3.22 \times 10^{11}$ copies per $\mu \mathrm{g}$ DNA.

\subsubsection{PCR and DNA sequence analysis}

The Q2N region of the genome of SVCV isolate RHV was amplified by PCR using 6 pairwise combinations of the following primers: SVCV-F N691 (5'-CAT GTT GTT AAA TCA CCG GTT TGA C-3'), SVCV-F N689 (5'-GAC ATG TTG TTA AAT CAC CGG TTT GAC-3'), SVCV-R N946 (5'-GTC TTG CGT TCA GTG CTC TCT TGG AG-3'), SVCV-R N998 (5'-GCC ATC AGC AGG CTT GCA TTT G-3') and SVCV-R N1067 (5'-GGC GGT TTT CTG TAT GTG TCT CC-3'). The RT reaction was performed as described in Section 2.1.2, and a $2.5 \mu \mathrm{l}$ portion was used as the PCR template. The amplicons (256$379 \mathrm{bp}$ ) were PCR amplified, separated by electrophoresis in $2 \%$ agarose gels, gel purified, sequenced and analyzed using the conditions described by Clouthier et al. (2013) with one exception. The PCR reactions with primer SVCV-F N691 were performed using an annealing temperature of $55^{\circ} \mathrm{C}$, and those with primer SVCV-F N689 were run at $57^{\circ} \mathrm{C}$.

\subsection{Diagnostic test development and optimization}

\subsubsection{Primer and probe design}

Two RT-qPCR tests were constructed to bind nucleoprotein (Q2N) and glycoprotein (Q1G) nucleotides of SVCV. The tests were designed to be sensitive and species-specific, inclusive of carp spriviviruses, and exclusive of pike fry spriviviruses as well other colocalizing viruses. Viruses in Table 1 were used to evaluate the primer and probe combinations for design of the 2 RT-qPCR tests. CyHV-3 and IPNV were included since they have been detected in cyprinid hosts susceptible to SVCV infections (Dixon 2008). The novirhabdoviruses HIRRV, VHSV and IHNV and the perhabdovirus MSRV share the same virus family as carp spriviviruses, and the pike fry spriviviruses share the same genus with carp spriviviruses. Nucleotide sequences present in the National Center for Biotechnology Information GenBank database (between August 2013 and October 2014) for the nucleoprotein and glycoprotein from members of the family Rhabdoviridae within the genera Sprivivirus, Perhabdovirus and Novirhabdovirus were aligned using ClustalW (Thompson et al. 1994) and T-Coffee (Notredame et al. 2000, Di Tommaso et al. 2011) (Fig. S2) and analyzed using BioEdit v7.0.9.0 software (Hall 1999). The software programs Beacon Designer, Allele ID (Premier Biosoft International) and Primer Express (Applied Biosystems) were used to identify potential Q1G and Q2N primers and Taqman probes.

\subsubsection{Primer and probe screening and optimization}

qPCR primer pair combinations (Q1G $\mathrm{n}=29$; Q2N $\mathrm{n}=14$ ) were analyzed with SYBR Green (ThermoFisher Scientific) using $800-900 \mathrm{nM}$ of each primer. Templates for the SYBR Green RT-qPCR tests were RNA extracted from whole cell lysates infected with SVCV isolates representing genotypes Ia through Id or pike fry sprivivirus isolates GrCRV or TenRV (traditional virus preparations). Amplicons were evaluated using dissociation curves. Primer pairs that failed to amplify all SVCV genotype templates or that amplified pike fry sprivivirus templates were removed from the study.

The Taqman RT-qPCR test parameters were incrementally selected using target RNA from 4 different sources: carp sprivivirus or pike fry sprivivirus-infected whole cell lysates (traditional), tissue samples containing exogenous SVCV HHOcarp06 RNA from infected whole-cell lysates (enriched), SVCV NC2002-infected kidney tissue and plasmid DNA encoding primer and probe binding sites (pAPC-Q2N, pAPC-Q1G). Tests were optimized by selecting for their ability to (1) detect SVCV isolates representing genotypes Ia through Id, (2) not detect pike fry sprivivirus isolates GrCRV or TenRV and (3) amplify plasmid DNA from $10^{7.7}$ to $10^{0.7}$ copies per reaction.

The iterative process of identifying the optimum primer and probe concentrations was described by Clouthier et al. (2015). Briefly, primer concentrations from 100 to $1000 \mathrm{nM}$ were tested in $100 \mathrm{nM}$ increments, and those producing the lowest quantification cycle (Cq) (Bustin et al. 2009) value with SVCV isolates and no $\mathrm{Cq}$ value with pike fry sprivivirus isolates were selected for further analysis. For this part of the study, the probe concentration was maintained at $250 \mathrm{nM}$. Probe concentrations from 100 to $250 \mathrm{nM}$ were then tested in increments of $50 \mathrm{nM}$, and those producing the highest fluorescence with representative SVCV isolates and no fluorescence with pike fry sprivivirus isolates were selected for further analysis. The effects of changing the annealing temperature $\left(60\right.$ to $\left.61^{\circ} \mathrm{C}\right)$ and adding an extension step $\left(72^{\circ} \mathrm{C}\right.$ for $30 \mathrm{~s}$ per cycle) were also evaluated. 
The optimum quantity of RNA to use in the Q2N and Q1G tests was identified by adding a range of RNA (i.e. 100, 250, 500, 750, 1000, 2000, 3000, 4000 and $5000 \mathrm{ng}$ ) extracted from either naïve carp kidney (Clouthier et al. 2017) or koi brain tissue (Clouthier et al. 2020) seeded with $50 \mathrm{ng}$ exogenous SVCV HHOcarp06 viral RNA from infected whole cell lysates (enriched).

\section{3. $R T-q P C R$ tests $Q 1 G$ and $Q 2 N$}

The Q2N test targets nucleoprotein-encoding nucleotides 854-950 (97 bp product) of GenBank accession number U18101 (Fig. S2). With the exception of SVCV isolate RHV, no base mismatches were observed in the SVCV N DNA sequences corresponding to the primer and probe binding sites (Fig. S2A). The primers and probes selected for the Q2N test were forward primer SVCV F2 (5'-CTG GAC AGG AGA TAG ATA A-3'), reverse primer SVCV R6 (5'-GAC GGA TTC TTT ATT GTT G-3') (MilliporeSigma), Q2N assay probe SVCV P6 (5'-6FAM-CTC TGC CAA ATC ACC AT-MGB-3') and positive control pAPC probe APC-P (5'-VIC-ACC GTC TAG CAT CCA GT- MGBNFQ-3') (Fig. S1A) (ThermoFisher Scientific). Each $25 \mu \mathrm{l}$ reaction contained 800 nM SVCV F2, 800 nM SVCV R6, 200 nM SVCV P6, 1× Taqman Universal PCR Master Mix (Applied Biosystems) and $1 \mu \mathrm{l}$ cDNA (optional 150 nM APC-P).

The Q1G test targets glycoprotein-encoding nucleotides 3643-3735 (93 bp product) of GenBank accession number U18101 (Fig. S2). Base mismatches were present in the primer and/or probe binding sites for most of the SVCV G DNA sequences (Fig. S2B). The primers and probes selected for Q1G test were forward primer SVCV F1400 (5'-ATT TGG ATC ACA GAT GAG AC-3'), reverse primer SVCV R400-11 (5'ATC CCC TCT CGG AGC ATT CCC GTA CA-3') (MilliporeSigma), Q1G assay probe SVCV P1000 (5'6FAM-TAG AGG AAG TTG AAG GAA TT-MGB-3') and the same pAPC probe APC-P described for the Q2N test (Fig. S1B) (ThermoFisher Scientific). Each $25 \mu$ reaction contained 900 nM SVCV F1400, 900 nM SVCV R400-11, 200 nM SVCV P1000, 1× Taqman Universal PCR Master Mix (Applied Biosystems) and $1 \mu \mathrm{l}$ cDNA (optional 200 nM APC-P).

The sample set for each RT-qPCR test run included positive and negative control samples that were used to validate the results obtained from nucleic acid extraction through to RT and qPCR. The Q1G and Q2N control material consisted of an RNA resuspension buffer blank (N1), 50 mg kidney tissue seeded with $0.466 \mathrm{ng}$ RNA from the SVCV HHOcarp06 enriched preparation (P1), water (N2), $8.8 \times 10^{-3} \mathrm{ng}$ RNA from the SVCV HHOcarp06 enriched preparation (P2), water (N3) and $5 \times 10^{4}\left(\mathrm{P}^{\mathrm{A}}\right.$; high copy number) and $5 \times 10^{2}(\mathrm{P} 3 \mathrm{~B}$; low copy number) copies of pSVCV-APC-Q1G per reaction or $5 \times 10^{5}\left(\mathrm{P} 3 \mathrm{~A}_{\text {; }}\right.$ high copy number) and $5 \times 10^{3}$ (P3B; low copy number) copies of pSVCV-APC-Q2N per reaction.

The control samples were added at the RNA extraction (N1, P1), RT (N2, P2) and the qPCR steps (N3, P3A, P3B) of each test. Since each set of control samples was run in parallel with unknown samples, the negative control samples were used to detect false positive results arising from cross-contamination between samples or from the positive control samples. The latter were used to detect false negative results such as those arising from machine malfunction or technical errors.

The P3 synthetic plasmid constructs pSVCV-APCQ2N and pSVCV-APC-Q1G each contain a binding site for the VIC-labeled probe APC-P, which can be added to each reaction mix (Fig. S1). As such, the Q2N and Q1G tests were designed to have 2 probes present in each qPCR reaction, with each probe labeled with a different fluorophore and recognizing a different target. The FAM-labeled probes P6 (Q2N) and P1000 (Q1G) bind with SVCV sequences found in the test sample or P3 plasmids pSVCV-APCQ2N or pSVCV-APC-Q1G (Fig. S1). The VIC-labeled probe APC-P only recognizes sequences found in the P3 plasmids (Fig. S1) and can be used to detect false positive results arising from cross-contamination of a test sample with P3A or P3B.

The qPCR tests were run in a 96-well format with replicates of 3-6 per sample on the Stratagene Mx3000/5P qPCR platform using the thermocycling profile of 1 cycle of $2 \mathrm{~min}$ at $50^{\circ} \mathrm{C}$ and 1 cycle of $10 \mathrm{~min}$ at $95^{\circ} \mathrm{C}$ followed by 40 cycles of $15 \mathrm{~s}$ at $95^{\circ} \mathrm{C}$ and $60 \mathrm{~s}$ at $60^{\circ} \mathrm{C}$. The $\mathrm{Cq}$ values were reported after manually adjusting the threshold to exceed the background level and be in the linear phase of the amplification curve. The copy number equivalent (i.e. equivalent plasmid copies, epc) present in each test sample was determined using the standard curve method with plasmids pSVCV-APC-Q1G or -Q2N.

\subsection{Analytical validation}

\subsubsection{Analytical sensitivity}

The analytical sensitivity of Q1G and Q2N was assessed with standard curves produced using (1) 
plasmid DNA (pSVCV-APC-Q1G, pSVCV-APCQ2N), (2) RNA extracted from whole cell lysates of EPC monolayers infected with SVCV HHOcarp06 or (3) RNA extracted from SVCV NC2002-infected kidney tissue. The reaction efficiency with each template was evaluated to determine if SVCV in infected tissue could be quantified using plasmid DNA as a proxy. Test parameters of reaction efficiency and ASe were also used to determine if host RNA (1500 ng per reaction) or the APC probe (150 or $200 \mathrm{nM}$ per reaction) altered assay performance. Nucleic acid was serially diluted 2-, 5- or 10-fold, and RT-qPCR standard curves were constructed from each dilution analyzed in replicates of 3,5 or 6 ( 5 dilution series with 6 replicates per dilution assessed in 5 independent qPCR runs). The concentration of nucleic acid in which 50 or $100 \%$ of the replicates were detected $(<40 \mathrm{Cq})$ was identified as the corresponding limit of detection (LOD) and was expressed as copies of plasmid DNA.

\subsubsection{Analytical specificity}

The exclusivity of Q1G and Q2N was determined using nucleic acid extracted from cell lysates (traditional virus preparation) infected with pike fry sprivivirus, novirhabdovirus, cyprinivirus or aquabirnavirus ( $\mathrm{n}=7$; Table 1 ) as well as plasmid DNA $\left(10^{6}\right.$ copies) encoding the full-length $\mathrm{N}$ or $\mathrm{G}$ gene from novirhabdovirus HIRRV or perhabdovirus MSRV $(\mathrm{n}=2$; Table 1$)$. The inclusivity of these assays was investigated using RNA isolated from cell lysates (traditional virus preparation) infected with carp spriviviruses ( $\mathrm{n}=22$; Table 1$)$ as well as plasmid DNA encoding the full-length $\mathrm{N}$ or $\mathrm{G}$ gene from SVCV 202238 ( $\mathrm{n}=1$; Table 1). Infected cell lysates were normalized to $10^{6} \mathrm{TCID}_{50} \mathrm{ml}^{-1}$. The RT was performed with $100 \mathrm{ng}$ RNA extracted from $1 \mathrm{ml}$ of this material (see Section 2.1 for RT and RNA extraction methods). The Q2N and Q1G tests were run in triplicate per sample using the parameters described in Section 2.3. The mean Cq values were reported so that the relative sensitivity of Q2N and Q1G with each isolate could be evaluated. The inclusivity of Q2N and Q1G was also evaluated using tissues from koi exposed to SVCV isolates 20040741, 20070165, 20100910, 20120450 or S30 ( $=5$; Table 1). In this case, the results were reported as detected or not detected. Using the binary results from all 37 viruses, inclusivity and exclusivity estimates were generated using 2-way cross-tabulation tables (Table 2) as the level of agreement between expected and observed
Table 2. Table used for determining analytical specificity of the $\mathrm{Q} 1 \mathrm{G}$ and $\mathrm{Q} 2 \mathrm{~N}$ tests. Inclusivity = A/(A + B ); Exclusivity = $\mathrm{D} /(\mathrm{C}+\mathrm{D})$

\begin{tabular}{|lccc|}
\hline & \multicolumn{3}{c|}{ Observed } \\
\cline { 2 - 4 } & Positive & Negative & Total \\
\hline Expected & & & \\
Positive & A & B & A + B \\
Negative & C & D & C + D \\
Total & A + C & B + D & A + B + C + D \\
\hline
\end{tabular}

results (with 95\% confidence intervals). For Q2N and Q1G, inclusivity represents the ability to detect $\mathrm{SVCV}$ isolates and exclusivity represents the degree to which the assay did not detect viruses outside of the carp spriviviruses.

\subsubsection{Analytical repeatability}

The intra- and inter-assay repeatability of Q1G and Q2N was tested in 5 runs with plasmid DNA (Q1G, pSVCV-APC-Q1G; Q2N, pSVCV-APC-Q2N) 10-fold serially diluted from $10^{8.7}$ to 5 , and 2-fold serially diluted from 25 to 0.78 copies per reaction (6 replicates per dilution). Continuous outcome data from the 2 tests for positive control samples P1, P2, P3A and P3B was also evaluated for repeatability using sample results from 1 batch of P1, P3A and P3B and 2 batches of $\mathrm{P} 2$ assessed in 31-69 independent runs performed by 3 or 4 analysts on 1 or 2 qPCR platforms (Stratagene Mx3000/5P; Applied Biosystems StepOne Plus) in 3 or 4 laboratories over a $3 \mathrm{yr}$ period. The Q2N and Q1G tests were run using the parameters described in Section 2.3. The results were presented graphically by plotting the mean $\mathrm{Cq}$ of the replicates against the standard deviation. Continuous outcome data (i.e. Cq values) variability was estimated as a ratio of the SD to the mean (i.e. coefficient of variation, CV). Statistical data analyses were implemented in StataI/C (v15.1).

\subsection{SVCV persistence in koi}

\subsubsection{Fish and virus exposure}

Shusui koi (10.5 mo, $3.4 \mathrm{~g}$ average weight, $6.6 \mathrm{~cm}$ average length) were initially held at $16-18^{\circ} \mathrm{C}$ in the aquatic laboratory at the US Geological Survey Western Fisheries Research Center (WFRC; Seattle, Washington). The koi were diagnosed as negative for 
CyHV-3 and SVCV prior to shipping. Fish were fed on alternate days with a mixed feed diet of Hikari Gold mini pellets (Kyorin Food Industries) and Classic Fry $1.5 \mathrm{~mm}$ floating pellets (Skretting). Immediately prior to challenge, fish were transferred on site to the aquatic biosafety level 3 laboratory where they were housed in 301 tanks containing water at $10-11^{\circ} \mathrm{C}$. Quadruplicate groups of 21 fish were challenged by immersion for $1 \mathrm{~h}$ in $3 \mathrm{l}$ aerated, static water containing SVCV $\left(10^{5} \mathrm{pfu} \mathrm{m}^{-1}\right)$ (Ia: 20040741, 20070165, 20100910, 20120450, NC2002; Ib: RHV; Ic: P4-7; Id: S30 [also known as Fijan]) or were mockchallenged in water containing an equivalent volume of cell culture media. Continuous water flow was restored and water temperature was increased $1^{\circ} \mathrm{C} \mathrm{d}^{-1}$ to $13-14^{\circ} \mathrm{C}$ and held at that temperature. The fish were monitored daily for $35 \mathrm{~d}$. Dead fish were removed on the day of death and immediately frozen at $-80^{\circ} \mathrm{C}$. The isolates and dose of SVCV were selected based on the virus exposure work of Emmenegger et al. (2018b), in which acute SVC disease was observed in younger Beni Kiko or Sanke koi (3.5 mo). Cumulative percent mortality (cpm) was determined in triplicate as the number of fish that died per tank divided by the total number of fish $\times 100$ and was reported as an average of the 3 tanks. A significant relationship was designated for cpm comparisons yielding $p$-values of $\leq 0.05$ using a 1 -way ANOVA and, if applicable, a Tukey-Kramer multiple-comparison test. This analysis was performed in GraphPad Prism 8 software. Mean day of death (MDD) values were calculated as the sum of the day(s) of death post-exposure divided by the total number of dead fish per tank. The average MDD for replicate tanks is reported. The study protocol was approved by the WFRC Institutional Animal Care and Use Committee and the WFRC Institutional Biosafety Committee under the guidelines provided in the Guide for the Care and Use of Laboratory Animals (NRC 2011).

\subsubsection{Targeted sampling}

Live fish $(\mathrm{n}=2)$ were removed $1,3,5,7,10,14$ and $17 \mathrm{~d}$ post exposure (dpe) from the fourth tank, euthanized and immediately frozen at $-80^{\circ} \mathrm{C}$. Fish that survived the $35 \mathrm{~d}$ challenge were pooled according to treatment and held in duplicate $30 \mathrm{l}$ tanks. Live fish ( $\mathrm{n}=2 ; 1$ per tank) were removed $35,49,63,77$ and 84 dpe, euthanized and immediately frozen at $-80^{\circ} \mathrm{C}$. At 93 dpe, fish were transferred to duplicate $10 \mathrm{l}$ tanks containing water at $10-11^{\circ} \mathrm{C}$. Water temperature was increased $1^{\circ} \mathrm{C} \mathrm{d}^{-1}$ to $13-14^{\circ} \mathrm{C}$ and held at that temperature. Live fish ( $\mathrm{n}=2$ or $3 ; 1$ or 2 per tank) were removed 133 and 149 dpe, euthanized and immediately frozen at $-80^{\circ} \mathrm{C}$. Any fish remaining at 149 dpe were used as donor fish in a cohabitation exposure study in which quadruple groups of 4 donor Shusui koi (i.e. convalescent) were held with 14 naïve Sanke koi fry $(1.5 \mathrm{mo}$, average weight $1.54 \mathrm{~g}$, average length $4.6 \mathrm{~cm}$ ) in 81 tanks containing water at $10-11^{\circ} \mathrm{C}$. The donor koi were anaesthetized in buffered tricaine methanesulfonate (MS222), and a portion of the left pelvic fin was removed to distinguish them from the naïve koi. Water temperature was increased $1{ }^{\circ} \mathrm{C} \mathrm{d}^{-1}$ to $13-14^{\circ} \mathrm{C}$ and held at that temperature. Live donor fish ( $\mathrm{n}=4 ; 1$ per tank) were removed $17 \mathrm{~d}$ into the cohabitation exposure (i.e. 167 dpe of the donor koi), euthanized and immediately frozen at $-80^{\circ} \mathrm{C}$. Fish were euthanized by an overdose of buffered MS222. Virus titer in each dead or sampled fish was determined as described in Section 2.1.

Additional fish were sampled over the course of this study, but an equipment failure of the $-80^{\circ} \mathrm{C}$ freezer compromised the samples and they were discarded. The samples described above had been processed prior to the mechanical failure with the exception of the following time point samples: 133 dpe, koi exposed to isolates 20040741, NC2002 or Fijan; 149 dpe, koi exposed to isolates 20040741, NC2002, Fijan, 20120450. These 14 fish are missing from the dataset.

\subsubsection{Statistical methods for analyzing Q2N and PA diagnostic test results}

Ordinary least-squares linear regression was performed to assess the significance (determined at $\mathrm{p}<$ 0.05 ) and relationship between variables.

The proportion of agreement and Cohen's kappa (Cohen 1960) statistics were used to estimate intertest and inter-fish concordance of Q2N and PA binary test outcomes. Results were interpreted according to Landis \& Koch (1977), and confidence intervals for kappa were calculated as described by Reichenheim (2004). Differences in the relative number of positive tests obtained by each test within a test pair were considered statistically significant if the $p$-value for McNemar's test statistic $\left(\chi^{2}\right)$ was $\leq 0.05$ (Dohoo et al. 2009).

Concordance correlation coefficient (Lin 1989, 2000) and Bland and Altman limits of agreement (Bland \& Altman 1986, Barnhart et al. 2007) were used as described previously (Clouthier et al. 2017) 
to evaluate the statistical agreement in virus titer results obtained with the Q2N and PA tests. Virus titer agreement within and between the 2 tests is presented as point estimates as well as graphically to identify patterns within the data.

All statistical analyses described in this section were performed in Stata/IC (v15.1).

\section{RESULTS}

\subsection{RT-qPCR Q2N and Q1G}

The Q2N and Q1G tests can be run with or without the VIC-based probe APC-P included in the reaction mix. The Q2N and Q1G FAM-based tests, when duplexed with the internal positive control VICbased probe APC-P, had similar reaction efficiencies to the respective VIC-based test (Fig. S3). The relative slopes of the qPCR standard curves for each test varied by less than 0.1 relative to the corresponding internal APC test (Fig. S3). The assays were linear across 9 orders of magnitude $\left(10^{8.7}\right.$ to $10^{0.7}$ copies) with a strong correlation between cycle number and dilution factor $\left(\mathrm{R}^{2}=0.995\right.$ to 0.998 , Fig. S3). In the absence of the VIC-labeled probe, amplification efficiencies of Q2N and Q1G qPCR reactions containing plasmid or SVCV-infected tissue or cell lysate RNA serially diluted 10 -fold ranged from -3.3 to -3.6 (Fig. S4). The similarities in reaction efficiencies independent of template type showed that plasmid DNA could be used to define the LOD for Q2N and Q1G. The poor reaction efficiency of the duplex Q2N/APC-P test (i.e. -4.1) suggested that Q2N test should not be multiplexed with the APC-P probe (Fig. S3A).

The RT-qPCR tests Q2N and Q1G could be performed with up to $5000 \mathrm{ng}$ total tissue RNA added to the RT reaction before interference in test performance was observed (data not shown). We typically add 1500 ng template RNA from brain or kidney tissue to the RT reaction.

\subsection{Analytical validation}

Plasmids pSVCV-APC-Q2N and pSVCV-APC-Q1G were used to determine the ASe for Q2N and Q1G (Fig. S5). The tests were positive with plasmid DNA present between $10^{8.7}$ and $10^{0.7}$ copies, or 8 or 9 orders of magnitude (Fig. S5). The observed 50\% LOD for $\mathrm{Q} 2 \mathrm{~N}$ and $\mathrm{Q} 1 \mathrm{G}$ was less than 3.13 copies of pSVCV-APC-Q2N (28 of 30 replicates tested posi- tive; $36.56 \pm 1.30$ [SD] Cq; Fig. S5B) or pSVCV-APCQ1G (21 of 30 replicates tested positive; $37.11 \pm 2.10$ Cq; Fig. S5D). The $100 \%$ LOD for Q2N was 5 copies of pSVCV-APC-Q2N (35.53 $\pm 1.00 \mathrm{Cq})$ and for Q1G, it was 12.5 copies of pSVCV-APC-Q1G (34.39 \pm $1.64 \mathrm{Cq}$ ). The presence of host RNA (1500 ng) did not significantly alter the LOD of either test, nor did the presence of the VIC-labeled probe APC-P in Q1G reactions (data not shown). The poor reaction efficiency of the duplex Q2N/APC-P test resulted in a significant shift in the LOD from 3.13 to $25(50 \%$ LOD) and from 5 to 50 (100\% LOD) copies (data not shown). The results indicated that the Q2N test should not be duplexed with the APC-P probe.

The ASp of Q2N and Q1G was determined using binary data (detected/not detected) to evaluate the level of agreement between the observed and expected status with the panel of viruses in Table 1. The carp sprivivirus isolates included representatives from the 4 genogroups Ia to Id. The inclusivity (including 95\% confidence intervals) of Q2N was $100 \%(88-100 \%)$ whereas for Q1G, it was $96 \%$ (82-100\%), as the test did not detect SVCV isolate 20120450. The relative ability (i.e. Cq value) of Q2N and Q1G to amplify different genogroups was evaluated with a subset of 22 carp sprivivirus isolates (Fig. 1). All of the isolates were detected within 21 cycles by Q2N except for RHV (24.73 Cq), and for Q1G, the exceptions were RHV $(24.13 \mathrm{Cq})$ and E134 (27.06 Cq) from genogroup Ib and 880110 (27.05 Cq) and 880124 (28.11 Cq) from genogroup Id (Fig. 1). The exclusivity of Q2N was 89\% (52-100\%) and for Q1G, it was $100 \%(66-100 \%)$. Q2N and Q1G did not recognize CyHV-3, IPNV, HIRRV, VHSV, IHNV or MSRV, and Q1G did not detect either pike fry sprivivirus tested (Table 1). Positive Q2N test results with an average $\mathrm{Cq}$ value of 36.21 were obtained with a pike fry sprivivirus isolate, V76 (Fig. 1).

Repeatability of Q1G and Q2N was investigated using $\mathrm{Cq}$ values obtained from 5 independent runs with plasmid DNA serially diluted from $10^{8.7}$ to $10^{-0.11}$ copies per reaction (6 replicates per dilution) (Fig. 2). The Cq values obtained for each dilution were also used to generate point estimates of variability expressed as the CV. The average intra-assay CV varied from 0.74 to 9.64 (Fig. 2) and the inter-assay CV ranged from 1.14 to 9.45 (Fig. 2). The widest dispersion of $\mathrm{Cq}$ values from the mean was observed with samples containing the highest plasmid copy number of $10^{8.7}$ copies (Fig. 2).

Repeatability of Q2N and Q1G was also investigated using $\mathrm{Cq}$ values obtained with positive control samples P1, P2, P3A and P3B (Fig. S6). The within- 


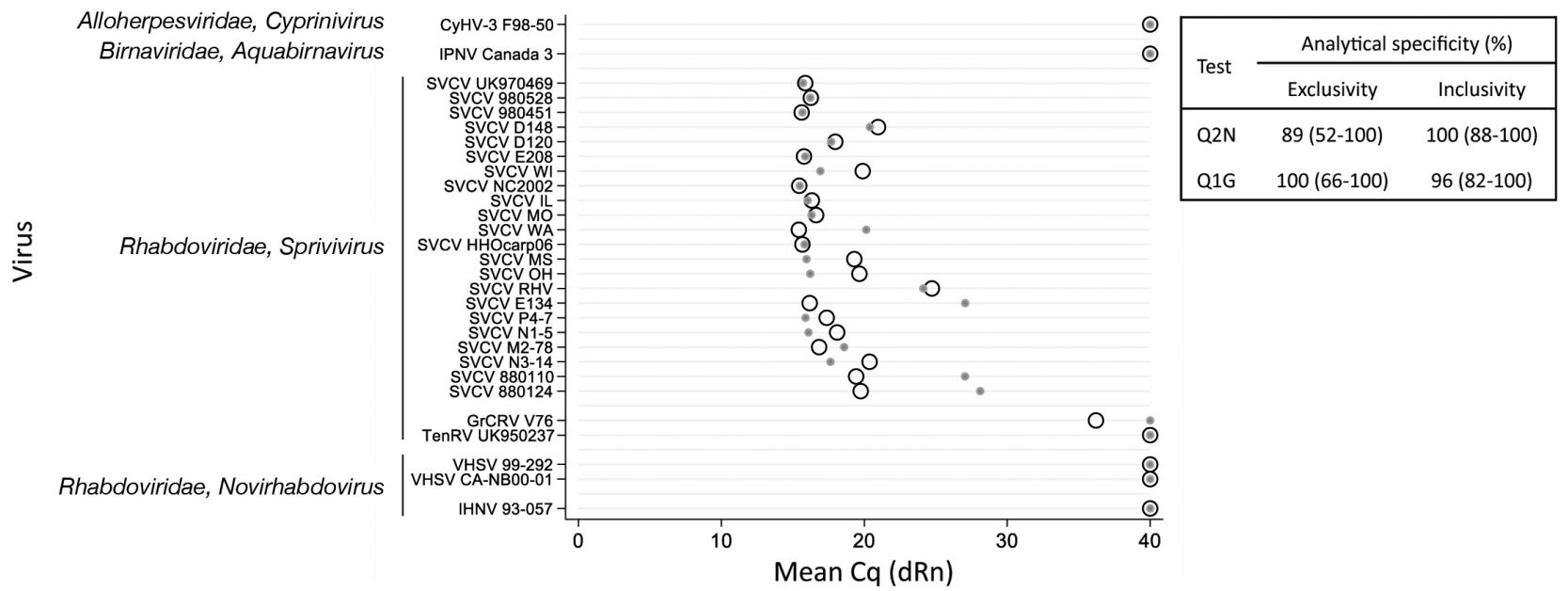

Fig. 1. Analytical specificity of spring viremia of carp virus diagnostic tests Q2N and Q1G. The relative specificity of the tests Q2N (०) and Q1G (॰) is demonstrated by differences in the mean quantification cycle (Cq) values obtained with and between select viruses (Table 1). The inclusivity and exclusivity of Q2N and Q1G (table inset) was determined using the binary test results defined as detected $(<40 \mathrm{Cq})$ or not detected $(40 \mathrm{Cq})$. dRn: ROX (carboxy-X-rhodamine)-normalized, baseline corrected fluorescence view

assay CV calculated on average for P1 was 1.16 for Q2N and 1.07 for Q1G, whereas the inter-assay CV was 4.66 for Q2N and 4.44 for Q1G (Fig. S6). The within-assay CV calculated on average for P2 was 1.28 for Q2N and 0.98 for Q1G whereas the interassay CV was 6.12 for Q2N and 6.60 for Q1G (Fig. S6). The average intra-assay CV calculated for P3A and P3B varied from 1.11 to 1.78 , whereas the inter-assay $\mathrm{CV}$ values ranged from 2.87 to 4.79 for both tests (Fig. S6).

\subsection{SVCV exposure of koi}

The exposure study was designed to investigate SVCV infection dynamics across genogroups in koi. The first part of the study, Days 0 through 35, was designed to measure the relative virulence (i.e. cumulative mortality) of 8 isolates of SVCV belonging to genogroups Ia to Id in koi, and the goal of the second part of the study, Days 0 through 167, was to measure the relative persistence (i.e. virus presence) of SVCV in koi. The virulence categories of each isolate were based on mortality and were established by Emmenegger et al. (2018b).

Cumulative mortality at the end of the $35 \mathrm{~d}$ study ranged from 3 to $26 \%$ (Fig. 3A) and was not significantly $(\mathrm{p}<0.05)$ different between treatments except for fish exposed to high virulence isolate 20040741 versus mock-infected fish and groups of fish exposed to the low virulence isolates RHV, 20100910 and 20070165. Of the virus-exposed fish that died, $60 \%$ $(9 / 15)$ displayed signs of disease, and of these, $44 \%$
(4/9) were exposed to highly virulent isolates. Clinical signs were first evident in fish exposed to highly virulent isolates and appeared 7-10 d following virus exposure. The MDD for the high virulence (i.e. 17 [NC2002], 23 [20040741] or 20 [Fijan] dpe), moderate virulence (i.e. 18 [20120450] or 24 [P4-7] dpe) and low virulence isolates (i.e. 20 [20070165], 15 [20100910] or 24 [RHV] dpe) suggested that the peak infection phase of the study occurred within the first $20 \mathrm{~d}$ following exposure (Fig. 3A). All of the fish that died in the first $35 \mathrm{~d}$ after virus exposure $(\mathrm{n}=15)$ were positive by PA, with titers ranging from $10^{5.51}$ to $10^{7.12} \mathrm{pfu}$ $\mathrm{g}^{-1}$ tissue. Virus was not detected in the 3 mockchallenged fish that died.

A targeted time point sampling study was undertaken in koi between 1 and 167 dpe following mock exposure or static immersion in 1 of $8 \mathrm{SVCV}$ isolates. For reference, whole body homogenates from 2 to 4 fish per virus isolate, per time point at $1,3,5,7,10$, $14,17,35,49,63,77,84,133,149$ and 167 dpe $(\mathrm{n}=$ $290)$ and from dead fish $(n=29)$ were tested for virus presence and titer using the PA and Q2N tests. The cumulative mortality is presented in Fig. 3B and virus presence and titer results are presented in Fig. 4.

Virus was detected by 1 or both tests in $83 \%(24 / 29)$ of fish that died on non-sampling days (Fig. 4). The Q2N test detected SVCV in more samples relative to the PA test (Q2N, 79\% [23/29]; PA, 38\% [11/29]). Virus titers ranged from $10^{2.7}$ to $10^{5.9} \mathrm{pfu} \mathrm{g}^{-1}$ tissue by PA and $10^{3.9}$ to $10^{9.2} \mathrm{epc}^{-1}$ tissue by qPCR. Virus was not detected in any of the mock-challenged fish.

Virus titer decreased significantly $(p<0.05)$ between 1 and 167 dpe (Fig. 4). Titer decreased daily 

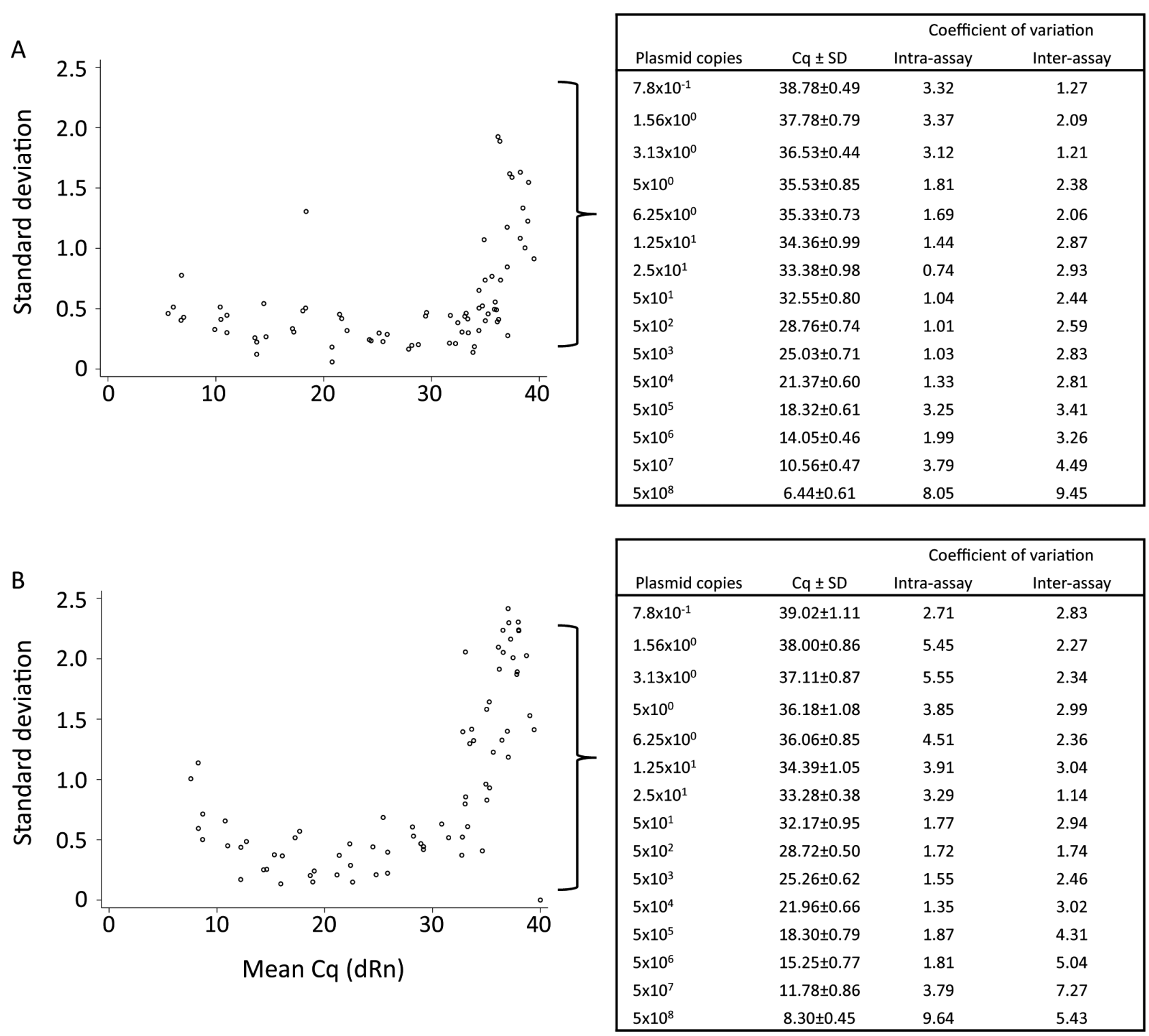

Fig. 2. Analytical repeatability of the (A) Q2N and (B) Q1G tests. Quantification cycle (Cq) values for the FAM-labeled probes were generated with plasmid pSVCV-APC-Q2N or pSVCV-APC-Q1G DNA diluted from $10^{8.7}$ to 0.78 copies (dRn: ROX-normalized, baseline corrected fluorescence view). Measurements were performed in replicates of 6 in 5 independent runs. Intraand inter-assay coefficient of variation for Cq values as well as the mean \pm SD Cq values for each of 5 runs are presented for each dilution in the tables, where $\mathrm{Cq}$ is the mean of the mean Cq per run, SD is the mean of the mean Cq SD per run, and the intra-assay CV is the average of the within-assay coefficient of variation for all runs

on average by $10^{0.03} \mathrm{epc}^{-1}$ tissue or $10^{0.04} \mathrm{pfu} \mathrm{g}^{-1}$ tissue. Virus was detected by 1 or both assays in at least 1 of the time point samples collected for each isolate in the first 35 dpe with the exception of Day 1. In the latter case, both assays tested negative with 5 of the 8 SVCV strains. Positive test results on Day 1 were obtained with isolates 20070165 and 20120450 (Q2N) and NC2002 (PA). RHV was detected by PA but not Q2N in fish collected at 3, 5, 7, 10, 63 and 77 dpe.
Virus prevalence measured by Q2N or PA increased significantly ( $p<0.05$ ) according to virulence category in fish sampled from 1 to 167 dpe (Fig. 4). For every change in virulence category from low to moderate and moderate to high, virus prevalence increased by $20 \%(\mathrm{Q} 2 \mathrm{~N})$ or $10 \%(\mathrm{PA})$.

Virus titer measured by Q2N or PA increased significantly ( $p<0.05$ ) according to virulence category in fish sampled from 1 to 167 dpe (Fig. 4). For every change in virulence category from low to moderate 

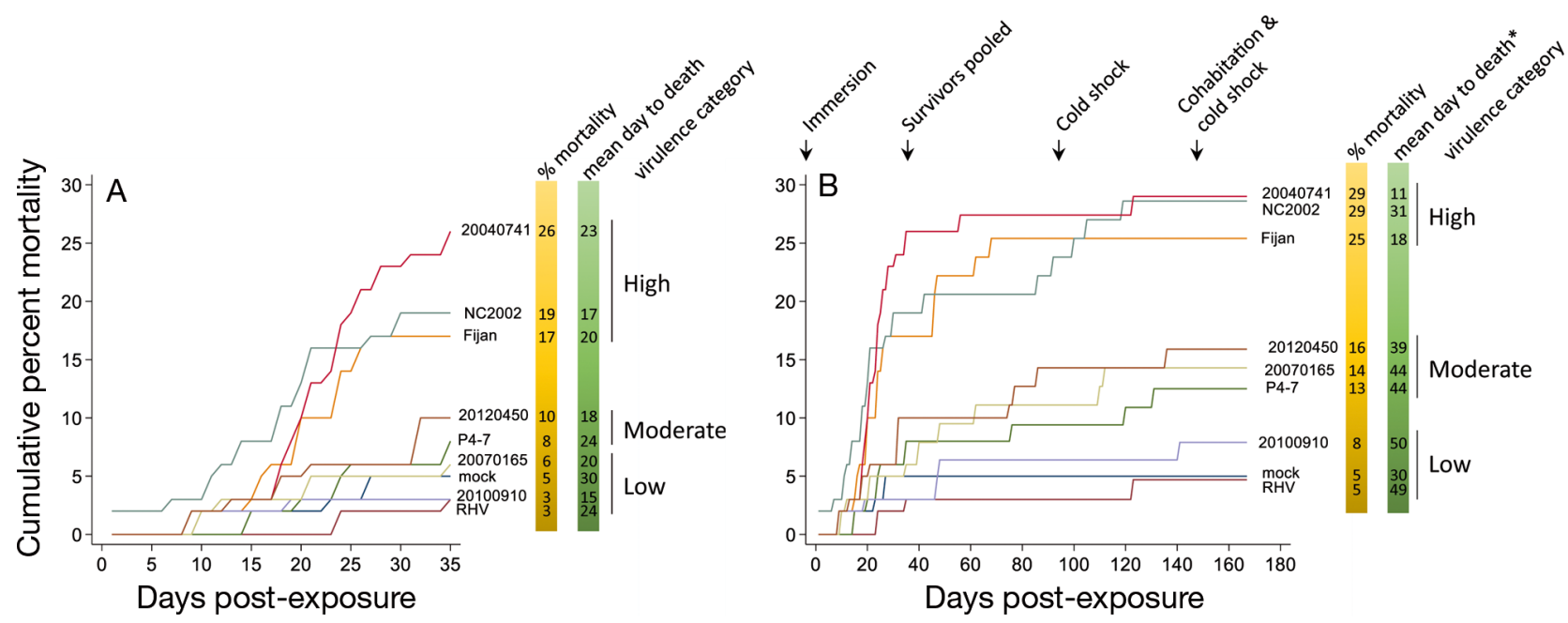

Fig. 3. Koi Cyprinus carpio L. exposed to spring viremia of carp virus (SVCV). The cumulative percent mortality and mean day to death are reported for groups of koi (3.4 g) (A) $35 \mathrm{~d}$ or (B) $167 \mathrm{~d}$ following immersion in no virus (mock) or $10^{5}$ plaque-forming units per ml of SVCV isolates RHV, P4-7, Fijan, NC2002, 20040741, 20120450, 20070165 or 20100910. Virulence categories were based on mortality and were established by Emmenegger et al. (2018b)

and moderate to high, virus titer increased by $10^{0.5}$ epc $\mathrm{g}^{-1}$ tissue or $10^{0.4} \mathrm{pfu} \mathrm{g}^{-1}$ tissue.

A significant $(\mathrm{p}<0.05)$ and positive relationship was observed between the maximum titer determined by Q2N or PA for each isolate and its virulence ranking (Fig. 4). For every change in virulence category from low to moderate and moderate to high, the maximum virus titer increased by $10^{0.9} \mathrm{epc} \mathrm{g}^{-1}$ tissue or $10^{0.4} \mathrm{pfu}^{-1}$ tissue in fish sampled from 1 to 167 dpe.

A significant $(p<0.05)$ and negative relationship was found for the time required to reach maximum virus titer and the virulence ranking of SVCV isolates (Fig. 4). For every change in virulence category from low to moderate and moderate to high, maximum virus titer determined using the PA test was obtained on average $2.5 \mathrm{~d}$ earlier.

The Q2N test but not the PA test detected virus after 77 dpe (Fig. 4). At 167 dpe, all 3 highly virulent isolates were detected by Q2N, and the percentage of positive fish was higher $(58 \%, 7 / 12)$ relative to the groups of fish infected with the moderate $(25 \%, 2 / 8)$ or low $(8 \%, 1 / 12)$ virulence isolates. No significant difference $(p>0.05)$ in virus titer was observed between genogroups using either test.

Agreement for binary outcomes (i.e. virus detected or not detected) for the PA and Q2N tests is reported in Table 3. Agreement of paired test results for duplicate fish $(\mathrm{n}=2 \times 127)$ ranged from $77(\mathrm{Q} 2 \mathrm{~N})$ to $87 \%$ (PA) (Table 3). Agreement between Q2N and PA test results was $71 \%$ for fish $(\mathrm{n}=128)$ sampled from 1 to 167 dpe (Table 3). Agreement increased to $87 \%$ when data were used from a subpopulation of fish with virus titers within the LOD of the PA (i.e. fish sampled from 1 to 17 dpe; data not shown). Within a sample set, sample pairs testing positive ranged in number from 51 for the Q2N test, 43 for the PA test and 52 between PA and Q2N (Table 3). Kappa estimates for paired test results were in the range of moderate to substantial categories for Q2N (0.54) and PA (0.74) and in the moderate agreement category between Q2N and PA (0.43). In the latter case, McNemar's test was significant $(\mathrm{p}<0.05)$ (Table 3).

Estimates of agreement for SVCV titer results from concordance correlation coefficients were 0.803 for Q2N, 0.249 for PA and 0.301 between Q2N and PA (Table 4). A concordance correlation plot of paired virus titer results from Q2N and PA is shown in Fig. 5A. The Bland-Altman average difference for pairwise comparisons of $\log _{10}$ virus titer values was 0.054 for Q2N, -0.154 for PA and -1.783 between Q2N and PA (Table 4). Virus titers estimated by the Q2N test were significantly higher $(p<0.05)$ compared to those of the PA test. A Bland and Altman plot for test pair results reported for Q2N and PA is presented in Fig. 5B.

\section{DISCUSSION}

The analytical performance characteristics of 2 SVCV-specific RT-qPCR tests, Q1G and Q2N, were validated according to international standards (OIE 2019d). The performance estimates for both tests 

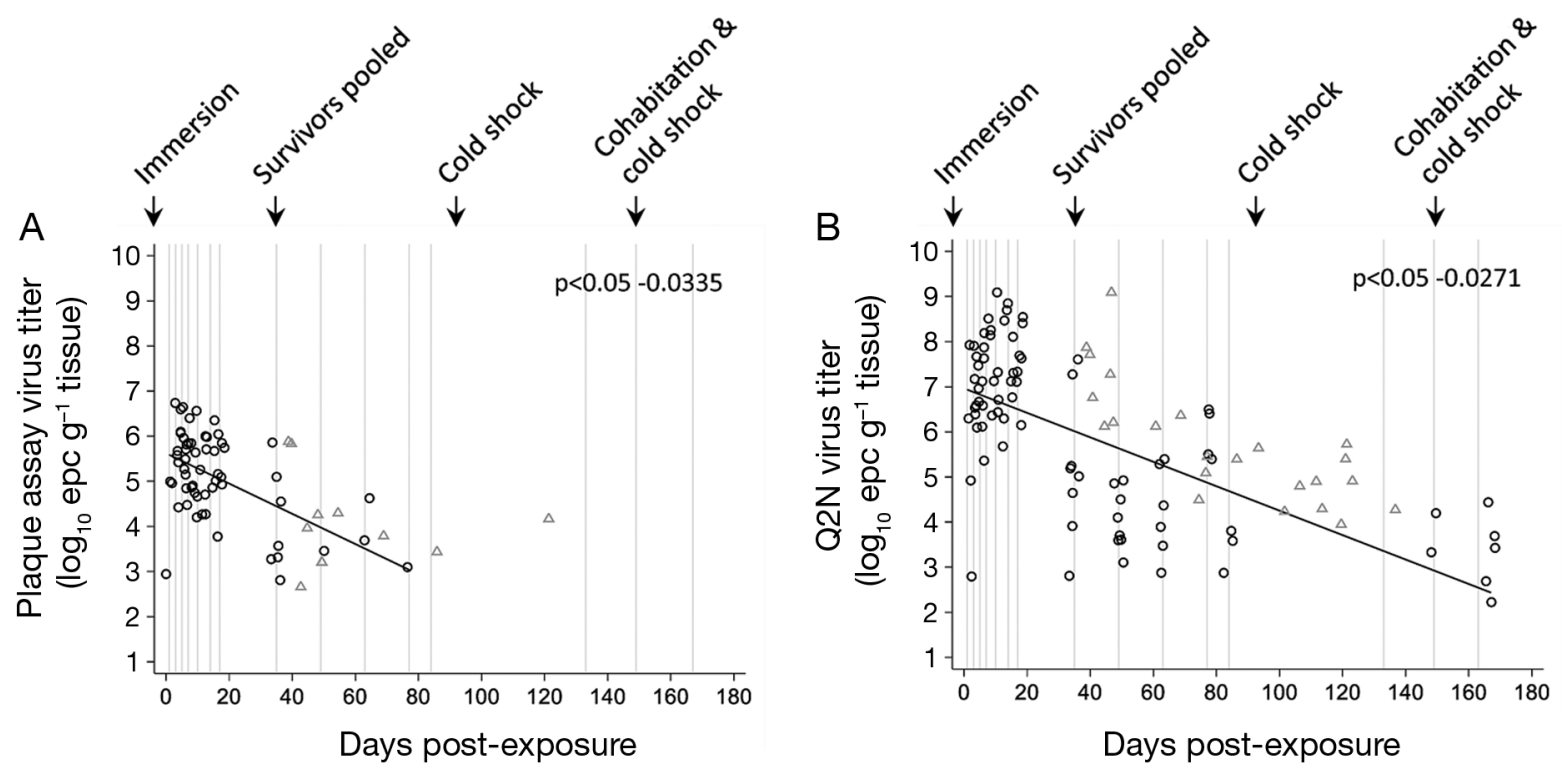

\begin{tabular}{|c|c|c|c|c|c|c|c|c|}
\hline \multirow{2}{*}{$\begin{array}{l}\text { Virus } \\
\text { category }\end{array}$} & \multirow[b]{2}{*}{ SVCV isolate } & \multicolumn{2}{|c|}{$\begin{array}{l}\text { Virus positive fish } 1 \text { to } 167 \mathrm{dpe} \\
\text { (\%) }\end{array}$} & \multicolumn{2}{|c|}{$\begin{array}{c}\text { Maximum titer } \\
\text { (log10 pfu or epc } \mathrm{g}^{-1} \text { tissue) }\end{array}$} & \multicolumn{2}{|c|}{$\begin{array}{l}\text { Time to maximum titer } \\
\text { (dpe) }\end{array}$} & \multirow{2}{*}{$\begin{array}{l}\text { Maximum positive } \\
\text { time point } \\
\text { (dpe) })^{*}\end{array}$} \\
\hline & & $\mathrm{PA}^{*}$ & Q2N* & $\mathrm{PA}^{*}$ & Q2N* & $\mathrm{PA}^{*}$ & Q2N & \\
\hline \multirow[t]{3}{*}{ High } & 20040741 & $50.00(14 / 28)$ & $82.14(23 / 28)$ & $10^{6.3}$ & $10^{8.7}$ & 7 & 14 & 167 \\
\hline & NC2002 & $57.14(16 / 28)$ & $85.71(24 / 28)$ & $10^{6.7}$ & $10^{8.6}$ & 7 & 17 & 167 \\
\hline & Fijan & $50.00(14 / 28)$ & $67.86(19 / 28)$ & $10^{6.6}$ & $10^{9.1}$ & 10 & 10 & 167 \\
\hline \multirow[t]{2}{*}{ Moderate } & 20120450 & $40.00(12 / 30)$ & $56.67(17 / 30)$ & $10^{5.7}$ & $10^{7.7}$ & 17 & 14 & 63 \\
\hline & P4-7 & $43.75(14 / 32)$ & $62.50(20 / 32)$ & $10^{6.6}$ & $10^{8.8}$ & 3 & 14 & 167 \\
\hline \multirow[t]{3}{*}{ Low } & 20070165 & $30.30(10 / 33)$ & $60.61(20 / 33)$ & $10^{5.7}$ & $10^{7.6}$ & 5 & 5 & 167 \\
\hline & 20100910 & $28.13(9 / 32)$ & $40.63(13 / 32)$ & $10^{5.8}$ & $10^{7.3}$ & 17 & 17 & 49 \\
\hline & RHV & $40.63(13 / 32)$ & $12.50(4 / 32)$ & $10^{5.9}$ & $10^{6.2}$ & 17 & 17 & 49 \\
\hline
\end{tabular}

Fig. 4. Koi Cyprinus carpio L. exposed to spring viremia of carp virus (SVCV). (A) Plaque assay (PA) test results expressed as $\log _{10}$ plaque-forming units (pfu) $\mathrm{g}^{-1}$ tissue and (B) Q2N test results expressed as $\log _{10}$ equivalent plasmid copies (epc) $\mathrm{g}^{-1}$ tissue. Results are displayed for fish sampled 1, 3, 5, 7, 10, 14, 17, 35, 49, 63, 77, 84, 133, 149 and 167 d post exposure (dpe) (i.e. time point fish, 0 ) and fish that died on non-sampling days (i.e. dead fish, $\Delta$ ). Virus titers for time point fish are the average of 2-4 fish collected per time point and virus isolate. A random jitter was added to expose the density of the data. Linear regression lines (solid black) and statistics are derived from time point data (1-167 dpe) indicated by grey vertical lines. Table inset presents the percent of fish that tested positive at 167 dpe, maximum virus titer and time to maximum titer obtained with the PA and Q2N tests. The maximum positive time point is the last time point at which virus was detected with either test. ${ }^{*}$ Linear regression $\mathrm{p}<0.05$ by virulence category

Table 3. Agreement of paired binary test results. Fish $(\mathrm{n}=2)$ were collected at time points $1,3,5,7,10,14,17,35,49,63,77$, 84, 133, 149 and 167 d post exposure. Test pairs indicate fish (fish 1, fish 2) and assay (PA: plaque assay; Q2N: RT-qPCR test). Symbols in parentheses describe the test results presented for test 1 and test 2, respectively. Estimates of between-fish or between-test agreement for binary outcomes were generated using the proportion of agreement and Cohen's kappa methods. Confidence intervals (95\%) accompany each kappa estimate. McNemar's test was significant for pairs of test results denoted with an asterisk ( $\left.{ }^{*}\right)$

\begin{tabular}{|c|c|c|c|c|c|c|c|}
\hline $\begin{array}{l}\text { Test pairs } \\
\text { (test 1, test 2) }\end{array}$ & $\overline{(+,+)}$ & $\begin{array}{r}2 \text { cont } \\
(+,-)\end{array}$ & $\begin{array}{l}\text { Jency table } \\
(-,+)\end{array}$ & $\overline{(-,-)}$ & $\begin{array}{c}\text { McNemar's } \\
\text { chi-squared p-value }\end{array}$ & $\begin{array}{c}\text { Agreement } \\
(\%)\end{array}$ & Cohen's kappa \\
\hline \multicolumn{8}{|l|}{ Q2N } \\
\hline $\begin{array}{l}\text { Fish 1, Fish } 2 \\
\text { PA }\end{array}$ & 51 & 16 & 13 & 47 & 0.7111 & 77.17 & $0.5431(0.397,0.689)$ \\
\hline $\begin{array}{l}\text { Fish 1, Fish } 2 \\
\text { PA \& Q2N }\end{array}$ & 43 & 8 & 8 & 68 & 1.0000 & 87.40 & $0.7379(0.618,0.858)$ \\
\hline PA, Q2N & 52 & 7 & 30 & 39 & $0.0002^{*}$ & 71.09 & $0.4343(0.290,0.579)$ \\
\hline
\end{tabular}


Table 4. Agreement of paired virus titer test results. Fish were collected at time points 1, 3, 5, 7, 10, 14, 17, 35, 49, 63, 77, 84, 133, 149 and 167 d post exposure. Test pairs indicate fish (fish 1, fish 2) and assay (PA: plaque assay; Q2N: RT-qPCR test). Confidence intervals (95\%) accompany each estimate

\begin{tabular}{lccc}
$\begin{array}{l}\text { Test pairs } \\
\text { (test 1, test 2) }\end{array}$ & $\begin{array}{c}\text { Concordance correlation coefficient } \\
\text { (Degree of agreement) }\end{array}$ & $\begin{array}{c}\text { Bland Altman's limit of agreement } \\
\text { (Average difference) }\end{array}$ & $\begin{array}{c}\text { Tests positive in } \\
\text { both sample sets }\end{array}$ \\
\hline $\begin{array}{l}\text { Q2N } \\
\text { Fish 1, Fish 2 }\end{array}$ & $0.803(0.681,0.882)$ & $0.054(-1.908,2.016)$ & 51 \\
PA & $0.249(-0.046,0.504)$ & $-0.154(-2.383,2.076)$ & 43 \\
$\begin{array}{l}\text { Fish 1, Fish 2 } \\
\text { PA \& QN }\end{array}$ & $0.301(0.184,0.409)$ & $-1.783(-3.564,-0.001)$ & 52 \\
PA, Q2N & & \\
\hline
\end{tabular}
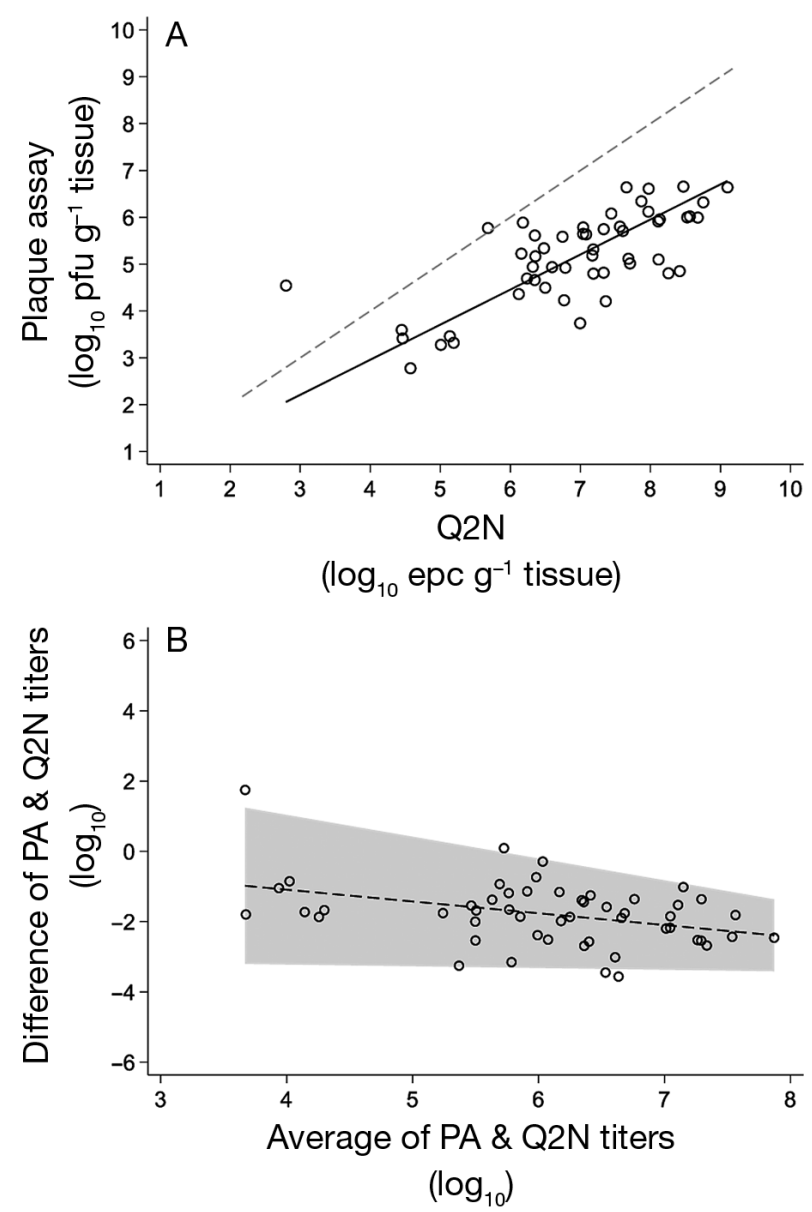

Fig. 5. Koi Cyprinus carpio L. exposed to spring viremia of carp virus. Pairwise analysis of Q2N and plaque assay (PA) average virus titer values for the same fish is presented in (A) the concordance correlation plot and (B) the Bland and Altman limits of agreement plot. In (A), the linear regression line of the test results is solid black, whereas the line of perfect concordance is dashed grey. In (B), $y=0$ is the line of perfect agreement; the difference in virus titer values determined using the PA and Q2N test is represented by the dotted line where the grey zone represents the $95 \%$ confidence interval approached their projected limits for sensitivity and repeatability and differed in their specificity. The linear range of the tests spanned at least 8 orders of magnitude, with ASe estimates for $100 \%$ LOD at 5 (Q2N) or 12.5 (Q1G) plasmid copies and >50\% LOD at $<3.13$ plasmid copies. The higher sensitivity of the Q2N test reflects the relative abundance of nucleoprotein transcripts in infected material (Rose \& Schubert 1987, Arakawa et al. 1990). The Q2N and Q1G tests yielded highly repeatable results both within and between runs. Thus the performance of the assays was consistent and reliable regardless of the virus load in the sample. The ASe of both tests is comparable to the sensitivity reported for other RTqPCR tests designed to detect SVCV (Liu et al. 2008, Yue et al. 2008, Zhang et al. 2009, Misk et al. 2016, 2017, Shao et al. 2016). Since the ASe and repeatability of the Q2N and Q1G tests were similar, selection of which test to use can be guided by the ASp requirements of the testing.

The lower genetic diversity within the SVCV N gene (Teng et al. 2007) increases the likelihood of detecting emerging isolates with the trade-off of potential false positive results with closely related viruses. The ASp of the Q2N test was pan-specific for $28 \mathrm{SVCV}$ isolates and exclusive of sympatric aquatic viruses except PFRV isolate GrCRV V76 (genus Sprivivirus). This means that the Q2N test was $100 \%$ inclusive detecting all of the carp sprivivirus isolates included in the study and $89 \%$ exclusive, since it did not detect other members of the family Rhabdoviridae tested or co-localizing viruses with the exception of GrCRV V76. In this case, despite sequence mismatches in 11 of the 55 nucleotides in the Q2N primer and probe binding regions, occasional amplification was observed. This finding indicates that the Q2N test may produce an SVCV false positive result if this isolate is present in a sample. The Cq value of 36.21 obtained with this isolate relative to the aver- 
age $\mathrm{Cq}$ value of 17.89 observed with the other isolates reflects the 6 orders of magnitude lower binding efficiency of the Q2N primers and probe with the target sequence from isolate V76 (assuming $3 \mathrm{Cq}$ is equivalent to $1 \log _{10}$ order of magnitude). The threshold GrCRV V76 titer in the starting material above which false positive results may be observed is approximated from these results at $4.84 \log _{10} \mathrm{pfu} \mathrm{g}^{-1}$. This titer is 2 logs lower than the titer in fish that died in the first $35 \mathrm{~d}$ following immersion exposure (i.e. average titer $6.88 \log _{10} \mathrm{pfu}^{-1}$ ) and 2 logs higher than the average titer in convalescent fish sampled between 49 and $167 \mathrm{~d}$ following initial exposure (i.e. average titer $2.9 \log _{10} \mathrm{pfu} \mathrm{g}^{-1}$ ). Based on these values, false positive results are more likely to be observed with samples from fish with high virus titers (e.g. fish originating from a population experiencing a disease outbreak) and unlikely to occur with samples from fish with low titers (e.g. fish from asymptomatic, apparently healthy populations). A false positive result would be resolved through genotype and phylogenetic analyses that occur following detection of a virus. The pan-specific detection by Q2N of all SVCV isolates tested suggests that false negative results are most likely to arise when diagnosing fish that are infected with SVCV at virus titers below the LOD of 5 plasmid copies or with isolates such as RHV with primer/probe base mismatches that reduce assay efficiency.

The ASp of the Q1G test was narrower than that of Q2N given that Q1G was unable to detect 20120450, an isolate originally detected in common carp. The isolate was identified as belonging to carp sprivivirus genogroup Ia by the SVC OIE reference laboratory Shenzhen Exit \& Entry Inspection and Quarantine Bureau (Shenzhen, China) (Emmenegger et al. 2018b). The false negative result obtained with Q1G is likely caused by 2 adjacent nucleotide mismatches located in the middle of the probe binding site. These results mean that the Q1G test was $96 \%$ inclusive, detecting all but 1 of the carp sprivivirus isolates included in the study and $100 \%$ exclusive since it did not detect other species within the genus Sprivivirus, family Rhabdoviridae or co-localizing viruses. The ASp of Q2N and Q1G is comparable to the exclusivity reported for other RT-qPCR tests designed to detect SVCV (Liu et al. 2008, Yue et al. 2008, Zhang et al. 2009, Misk et al. 2016, 2017, Shao et al. 2016).

Genetic changes observed in the Q1G target sequences represent a possible risk of future false negative results such as those obtained with isolate 20120450. Predicting genetic change in a viral genome as a result of evolution is difficult, but patterns have emerged from analyzing the dynamics of virus evolution (Salama et al. 2016). For example, immune selection (i.e. genetic mutation) occurs in genes encoding virus surface proteins in response to neutralizing antibodies produced by infected hosts. The latter are produced in response to SVCV infection in carp (Sulimanovic 1973, Hill et al. 1975, Fijan et al. 1977) and to vesiculoviruses, the closest relatives to spriviviruses (Björklund et al. 1996, Dietzgen et al. 2017), which show evidence of immune selection in the G protein sequence (Kelley et al. 1972, Vandepol et al. 1986, Munis et al. 2018). The region encoded by the Q1G target sequence (pre-cleavage amino acids 184-214) does not overlap with regions encoding neutralizing epitopes predicted for SVCV (Luo et al. 2014, Zhu et al. 2019) or vesicular stomatis virus (VSV) (Vandepol et al. 1986, Keil \& Wagner 1989, Munis et al. 2018). Nevertheless, viral adaptation due to immune selection or other selection pressures acting in this region may pose a potential risk for future false negative results if nucleotide changes occur in the Q1G target sequence.

Structural and amino acid sequence comparisons of the VSV and SVCV glycoproteins show that the Q1G target sequence encodes a region that corresponds to the junction of the VSV G pleckstrin homology domain and the fusion domain (Roche et al. 2006, 2007). This region functions as a hinge which refolds during the $\mathrm{pH}$-induced conformational change of the G protein from pre- to post-fusion forms (Roche et al. 2007). Sequence changes in this region would affect $\mathrm{G}$ protein structural rearrangement and membrane fusion and may either enhance or interfere with virus infection. Nucleotide sequence alignment analyses reveal that changes are occurring in this area of the SVCV genome. For example, maximum likelihood-based codon substitution analyses by Padhi \& Verghese $(2008,2012)$ suggest that amino acids 216 and 217 of the SVCV glycoprotein are under positive selection. These residues do not include the region encoded by the Q1G target sequence but are immediately proximal and correspond to the 4 -amino acid region (i.e. amino acids 215 to 218) identified by Zhang et al. (2009) as different in SVCV isolates from China. The variable amino acid residues at codon 216 are predicted to have little effect on functional divergence. Positive selection of codon 217 is specific to genogroup Ia. The occurrence of nucleotide changes within the Q1G target sequence in a genogroup Ia isolate (i.e. 20120450) is consistent with the observation of Padhi \& Verghese (2012) that isolates within genogroup Ia are exhibiting a mean nucleotide substitution rate 
across the glycoprotein gene of at least 5-7 times higher than their Id counterparts. Thus, a false negative result arising from a loss of target specificity is more likely to occur via a mutation event in Ia isolates. The likelihood of detecting changes in the ASp of Q1G is increased using a combination of tests like Q1G, Q2N and/or virus isolation and through periodic assessment of the ability of the test to detect emerging rhabdoviruses.

The Q2N test was used in parallel with a PA to detect virus and measure the relative virus abundance in koi following waterborne exposure to 1 of 8 isolates of SVCV from genogroups Ia to Id. SVCV was more abundant in fish sampled at earlier time points compared to asymptomatic convalescent fish that survived infection. Among the convalescent fish, the PA detected fewer positive fish compared to the Q2N test. This pattern was also observed by Dixon (2008), who found that SVCV could be isolated using cell culture from clinically infected fish but not from fish surviving infection. These results suggest that the ASe of cell culture-based tests for detection of SVCV is lower than that of the Q2N test. Thus, the more sensitive RT-qPCR Q2N or Q1G tests would be the preferred screening tests to use in surveillance programs that target apparently healthy populations of individuals in which pathogen load is likely to be low. In the latter case, confirmation of a positive test result achieved with either Q2N or Q1G may not be possible with the cell culture-based test. In the case of Q2N, this zone of uncertainty starts at virus loads below $6.5 \log _{10}$ epc $^{-1}$ tissue $(\mathrm{Cq}>32.2$; Fig. 6A). A notable exception to this trend was observed with SVCV isolate RHV. In this case, the PA was more sensitive than Q2N in detecting virus at the earlier time points as well as in convalescent fish (Fig. 6B). The lower efficiency of Q2N is evident in the Cq value of 24.73 obtained with this isolate versus the average Cq value of 17.56 observed with the other SVCV isolates. This shift represents a loss of least 2 orders of magnitude in the ASe of Q2N and is likely due to a single base mismatch (A to G) near the $3^{\prime}$ end of the reverse primer (Fig. S2). The reversal in the relative ASe of the 2 tests highlights the importance of designing diagnostic workflows that incorporate different techniques for detecting the virus.

With the exception of RHV, the SVCV isolates displayed the same virulence ranking (based on mortality) in koi in this study as determined by Emmenegger et al. (2018b): high, China 20040741, Fijan, NC2002; moderate, China 20120450, P4-7; low, China 20070165, 20100910. RHV grouped with the low rather than the moderate virulence isolates in our
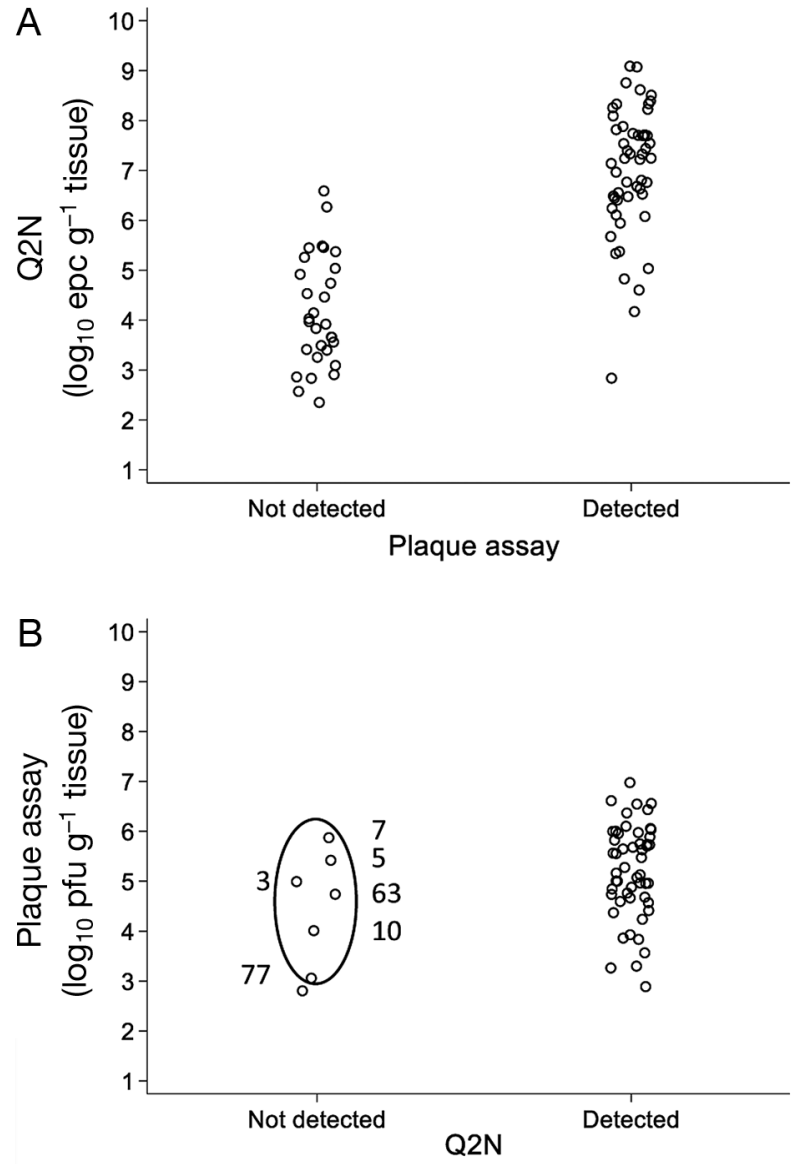

Fig. 6. Koi Cyprinus carpio L. exposed to spring viremia of carp virus (SVCV). Plaque assay (PA) and Q2N test results for koi collected between 1 and $167 \mathrm{~d}$ after exposure to SVCV. Virus titer is reported using (A) the Q2N test as $\log _{10}$ equivalent plasmid copies (epc) $\mathrm{g}^{-1}$ tissue and (B) as $\log _{10}$ plaque-forming units (pfu) $\mathrm{g}^{-1}$ tissue with the PA. Samples from isolate RHV-exposed fish that tested negative with the Q2N test but positive with the PA are circled in (B) and are labeled with the number of days after virus exposure when the sample was collected. A random jitter was added to expose the density of the data

study. The lower cumulative mortality observed in our study may be related to the genotype and/or older age of the koi population (Shchelkunov \& Shchelkunova 1989). Viremia due to SVCV is typically established following virus entry and dissemination from epithelial surfaces, particularly gill epithelia, to the blood and then internal organs including kidney and liver (Ahne 1977, 1978). Our finding of virus-exposed but not infected fish suggests that some fish are non-susceptible to SVCV. The MDD for the high virulence isolates was 17 (NC2002), 23 (20040741) or 20 (Fijan) dpe, suggesting that the peak infection phase of the exposure study occurred 
within the first $20 \mathrm{~d}$ following exposure. Not all fish showed clinical signs of infection, but initial signs were observed 7-10 d following exposure to the high virulence isolates. We used experimental conditions similar to those described by Ahne (1978) which explains the comparable infection kinetics we observed for virus incubation (i.e. $7 \mathrm{dpe}$ ) and peak mortality (i.e. $20 \mathrm{dpe}$ ). Using this $13 \mathrm{~d}$ window of time to identify non-susceptible fish and evaluate their prevalence, we found that all of the fish that tested negative by both tests were from populations exposed to the low virulence isolates (9\% prevalence) with the exception of 1 fish exposed to the moderate 20120450 isolate ( $2 \%$ prevalence). This inverse relationship was also observed from 35 to 167 dpe when the prevalence of non-susceptible fish increased with decreasing virus virulence in populations exposed to high $(8 \%)$, moderate $(15 \%)$ or low $(30 \%)$ virulence isolates. A serology-based test could help distinguish non-susceptible fish that are resistant to infection from those that are resistant to disease.

Clustering the SVCV isolates based on their previously established virulence categories provided a framework for evaluating their infection kinetics. SVCV prevalence, titer, replicative rate and persistence correlated significantly with virulence (Fig. 4). The quantity of replicating virus was lower on average by $1.8 \log _{10}$ relative to the quantity of nucleoprotein RNA, with peak production of both virus and RNA occurring in a similar time frame except for 2 high virulence isolates. In those cases, RNA production was high at earlier time points but peaked 7 to $10 \mathrm{~d}$ following peak production of replicating virus, suggesting that these isolates were able to produce more virus and then sustain high levels of nucleoprotein RNA production for longer. The analyses revealed that high virulence isolates were present in more fish, reached higher titers in shorter periods of time and persisted for longer in fish relative to moderate and low virulence isolates. These results suggest that SVCV virulence may be driven by multiple viral fitness traits including virus replication and virus persistence, in which the latter implies continued virus replication (as described by Kane \& Golovkina 2010). These biological traits are similar to those of VSV whose hallmark feature is its rapid replication (Hastie et al. 2013). The slower replication rate of the less virulent isolates in our study may have facilitated the ability of the host immune system to resist or limit infection and clear the virus. The decline in virus titer over time for isolates from all virulence categories suggests that if SVCV persistence requires continuous virus replication, then it likely occurs at a limited rate and in a select group of cells as shown for other RNA viruses of fish (Dahle \& Jørgensen 2019). Persistence of highly virulent SVCV in survivors may lead to chronic disease or cycles of reactivated disease. Cycling of the virus in a temperature-dependent manner between persistent and acute infection stages in spawning fish could create a virus reservoir as well as a transmission pathway that maintains the virus within a population. Without a test capable of detecting low virus loads in survivors, movement of these fish represents a potential risk for introducing SVCV into a naïve population of susceptible fish or aquatic organisms. The RT-qPCR tests Q2N and Q1G reduce this risk and provide a method for evaluating the molecular mechanism by which SVCV establishes a persistent infection.

Acknowledgements. This study was supported by the Centre of Expertise for Aquatic Animal Health Research \& Development (Fisheries and Oceans Canada) and the Emerging Diseases Cyclical Fund (US Geological Survey). We thank Ron Hedrick and Tomo Kurobe for CyHV-3 isolate F98-50; Kyle Garver for the VHSV and IHNV isolates; and David Stone, Andrew Goodwin, Peng Jia and Hong Liu for the carp and pike fry sprivivirus isolates. Any use of trade, firm or product names is for descriptive purposes only and does not imply endorsement by the US government.

\section{LITERATURE CITED}

Ahne W (1977) Evidence for the systemic character of Rhabdovirus carpio infection. Bull Off Int Epizoot 87:435-436

Ahne W (1978) Uptake and multiplication of spring viraemia of carp virus in carp, Cyprinus carpio L. J Fish Dis 1: 265-268

Ahne W, Bjorklund HV, Essbauer S, Fijan N, Kurath G, Winton JR (2002) Spring viremia of carp (SVC). Dis Aquat Org 52:261-272

Arakawa CK, Deering RE, Higman KH, Oshima KH, O'Hara PJ, Winton JR (1990) Polymerase chain reaction (PCR) amplification of a nucleoprotein gene sequence of infectious hematopoietic necrosis virus. Dis Aquat Org 8: 165-170

* Bachmann PA, Ahne W (1974) Biological properties and identification of the agent causing swimbladder inflammation in carp. Arch Gesamte Virusforsch 44:261-269

* Barnhart HX, Haber MJ, Lin LI (2007) An overview on assessing agreement with continuous measurements. J Biopharm Stat 17:529-569

Batts WN, Winton JR (1989) Enhanced detection of infectious hematopoietic necrosis virus and other viruses by pretreatment of cell monolayers with polyethylene glycol. J Aquat Anim Health 1:284-290

* Bekesi L, Csontos L (1985) Isolation of spring viraemia of carp virus from asymptomatic broodstock carp, Cyprinus carpio L. J Fish Dis 8:471-472

Björklund HV, Higman KH, Kurath G (1996) The glycoprotein genes and gene junctions of the fish rhabdoviruses spring viremia of carp virus and hirame rhabdovirus: analysis of relationships with other rhabdoviruses. Virus Res 42:65-80 
Bland JM, Altman DG (1986) Statistical methods for assessing agreement between two methods of clinical measurement. Lancet 327:307-310

Bustin SA, Benes V, Garson JA, Hellemans J and others (2009) The MIQE guidelines: minimum information for publication of quantitative real-time PCR experiments. Clin Chem 55:611-622

CFIA (2019) Federally reportable aquatic animal diseases in Canada - 2019. www.inspection.gc.ca/animals/aquaticanimals/diseases/reportable/2019/eng/1339174937153/ 1339175227861 (accessed 4 December 2019)

Clark HF, Soriano EZ (1974) Fish rhabdovirus replication in non-piscine cell culture: new system for the study of rhabdovirus-cell interaction in which the virus and cell have different temperature optima. Infect Immun 10: 180-188

* Clouthier SC, VanWalleghem E, Copeland S, Klassen C, Hobbs G, Nielsen O, Anderson ED (2013) A new species of nucleo-cytoplasmic large DNA virus (NCLDV) associated with mortalities in Manitoba lake sturgeon Acipenser fulvescens. Dis Aquat Org 102:195-209

* Clouthier SC, VanWalleghem E, Anderson ED (2015) Sturgeon nucleo-cytoplasmic large DNA virus phylogeny and PCR tests. Dis Aquat Org 117:93-106

Clouthier SC, McClure C, Schroeder T, Desai M and others (2017) Diagnostic validation of three test methods for detection of cyprinid herpesvirus 3 (CyHV-3). Dis Aquat Org 123:101-122

Clouthier SC, McClure C, Schroeder T, Aldous S and others (2021) Measures of diagnostic precision (repeatability and reproducibility) for three test methods designed to detect spring viremia of carp virus. Prev Vet Med https:// doi.org/10.1016/j.prevetmed.2021.105288

Cohen JA (1960) A coefficient of agreement for nominal scales. Educ Psychol Meas 20:37-46

Dahle MK, Jørgensen JB (2019) Antiviral defense in salmonids - mission made possible? Fish Shellfish Immunol 87:421-437

Di Tommaso P, Moretti S, Xenarios I, Orobitg M and others (2011) T-Coffee: a web server for the multiple sequence alignment of protein and RNA sequences using structural information and homology extension. Nucleic Acids Res 39:W13-W17

* Dietzgen RG, Kondo H, Goodin MM, Kurath G, Vasilakis N (2017) The family Rhabdoviridae: mono- and bipartite negative-sense RNA viruses with diverse genome organization and common evolutionary origins. Virus Res 227: 158-170

Dikkeboom AL, Radi C, Toohey-Kurth K, Marcquenski S, Engel M, Goodwin AE (2004) First report of spring viremia of carp virus (SVCV) in wild common carp in North America. J Aquat Anim Health 16:169-178

Dixon PF (2008) Virus diseases of cyprinids. In: Eiras JC, Segner H, Wahli T, Kapoor BG (eds) Fish diseases, Vol 1. Science Publishers, Enfield, NH, p 87-184

Dohoo IR, Martin W, Stryhn H (2009) Veterinary epidemiologic research, $2^{\text {nd }}$ edn. VER Inc., Charlottetown

Emmenegger EJ, Biacchesi S, Merour E, Glenn JA, Palmer AD, Bremont M, Kurath G (2018a) Virulence of a chimeric recombinant infectious haematopoietic necrosis virus expressing the spring viraemia of carp virus glycoprotein in salmonid and cyprinid fish. J Fish Dis 41:67-78

Emmenegger EJ, Bueren EK, Jia P, Liu H (2018b) Virulence of spring viremia of carp virus (SVCV) strains in two koi stocks. International Symposium on Aquatic Animal
Health, September 2-6, Charlottetown, Prince Edward Island, Canada.

Faisal M, Ahne W (1984) Spring viremia of carp virus (SVCV): comparison of immunoperoxidase, fluorescent antibody and cell culture isolation techniques for detection of antigen. J Fish Dis 7:57-64

Fijan N (1999) Spring viremia of carp and other viral diseases of warm-water fish. In: Woo PTK, Bruno DW (eds) Fish diseases and disorders, Vol 3. Viral, bacterial and fungal infections. CAB International, Wallingford, p 177-244

Fijan N, Petrinec Z, Sulimanovic D, Zwillenberg LO (1971) Isolation of the viral causative agent from the acute form of infectious dropsy of carp. Vet Arh 41:125-138

Fijan N, Petrinec Z, Stancl Z, Dorson M, Le Berre M (1977) Hyperimmunization of carp with Rhabdovirus carpio. Bull Off Int Epizoot 87:439-440

Fijan N, Sulimanović D, Bearzotti M, Mužinić D and others (1983) Some properties of the epithelioma papulosum cyprini (EPC) cell line from carp Cyprinus carpio. Ann Inst Pasteur Virol 134:207-220

* Gagné N, MacKinnon AM, Boston L, Souter B, CookVersloot M, Griffiths S, Olivier G (2007) Isolation of viral haemorrhagic septicaemia virus from mummichog, stickleback, striped bass and brown trout in eastern Canada. J Fish Dis 30:213-223

Garver KA, Dwilow AG, Richard J, Booth TF, Beniac DR, Souter BW (2007) First detection and confirmation of spring viraemia of carp virus in common carp, Cyprinus carpio L., from Hamilton Harbour, Lake Ontario, Canada. J Fish Dis 30:665-671

*Garver KA, Mahony AAM, Stucchi D, Richard J, Van Woensel C, Foreman M (2013) Estimation of parameters influencing waterborne transmission of infectious hematopoietic necrosis virus (IHNV) in Atlantic salmon (Salmo salar). PLOS ONE 8:e82296

Goodwin A (2002) First report of spring viremia of carp virus (SVCV) in North America. J Aquat Anim Health 14: 161-164

Hall TA (1999) BioEdit: a user-friendly biological sequence alignment editor and analysis program for Windows 95/98/NT. Nucleic Acids Symp Ser 41:95-98

*Hastie E, Cataldi M, Marriott I, Grdzelishvili VZ (2013) Understanding and altering cell tropism of vesicular stomatitis virus. Virus Res 176:16-32

*Hedrick RP, Gilad O, Yun S, Spangenberg JV and others (2000) A herpesvirus associated with mass mortality of juvenile and adult koi, a strain of common carp. J Aquat Anim Health 12:44-57

Hill BJ, Underwood BO, Smale CJ, Brown F (1975) Physicochemical and serological characterization of five rhabdoviruses infecting fish. J Gen Virol 27:369-378

ICTV (International Committee on Taxonomy of Viruses) (2019) Virus taxonomy: 2019 Release. https://talk. ictvonline.org/taxonomy/ (accessed 13 May 2020)

* Ip HS, Lorch JM, Blehert DS (2016) Detection of spring viraemia of carp virus in imported amphibians reveals an unanticipated foreign animal disease threat. Emerg Microbes Infect 5:e97

Kane M, Golovkina T (2010) Common threads in persistent viral infections. J Virol 84:4116-4123

*Kärber G (1931) Beitrag zur kollektiven Behandlung pharmakologischer Reihenversuche. Naunyn Schmiedebergs Arch Exp Pathol Pharmakol 162:480-483

Keil W, Wagner RR (1989) Epitope mapping by deletion mutants and chimeras of two vesicular stomatitis virus 
glycoprotein genes expressed by a vaccinia virus vector. Virology 170:392-407

Kelley JM, Emerson SU, Wagner RR (1972) The glycoprotein of vesicular stomatitis virus is the antigen that gives rise to and reacts with neutralizing antibody. J Virol 10:1231-1235

Kim DH, Oh HK, Eou JI, Seo HJ and others (2005) Complete nucleotide sequence of the hirame rhabdovirus, a pathogen of marine fish. Virus Res 107:1-9

Landis JR, Koch GG (1977) The measurement of observer agreement for categorical data. Biometrics 33:159-174

Lannan CN, Winton JR, Fryer JL (1984) Fish cell lines: establishment and characterization of nine cell lines from salmonids. In Vitro 20:671-676

Lin LI (1989) A concordance correlation coefficient to evaluate reproducibility. Biometrics 45:255-268

Lin LI (2000) A note on the concordance correlation coefficient. Biometrics 56:324-325

Liu Z, Teng Y, Liu H, Jiang Y and others (2008) Simultaneous detection of three fish rhabdoviruses using multiplex real-time quantitative RT-PCR assay. J Virol Methods 149:103-109

* Luo P, Ruan X, Zhang Q, Li Z, Wang M, Liu X (2014) Monoclonal antibodies against $\mathrm{G}$ protein of spring viremia of carp virus. Monoclon Antib Immunodiagn Immunother 33:340-343

Lyu SJ, Yuan XM, Zhang HQ, Shi WD, Hang XY, Liu L, Wu YL (2019) Isolation and characterization of a novel strain (YH01) of Micropterus salmoides rhabdovirus and expression of its glycoprotein by the baculovirus expression system. J Zhejiang Univ Sci B 20:728-739

Macdonald RD, Moore AR, Souter BW (1983) Three new strains of infectious pancreatic necrosis virus isolated in Canada. Can J Microbiol 29:137-141

Miller O, Fuller FJ, Gebreyes WA, Lewbart GA and others (2007) Phylogenetic analysis of spring viremia of carp virus reveals distinct subgroups with common origins for recent isolates in North America and the UK. Dis Aquat Org 76:193-204

Misk E, Garver K, Nagy E, Isaac S and others (2016) Pathogenesis of spring viremia of carp virus in emerald shiner Notropis atherinoides Rafinesque, fathead minnow Pimephales promelas Rafinesque and white sucker Catostomus commersonii (Lacepede). J Fish Dis 39:729-739

Misk E, Tubbs L, Garver K, Isaac S, Wright E, Al-Hussinee L, Lumsden JS (2017) Spring viremia of carp virus: a RTqPCR assay and surveillance in Ontario from 2008 to 2012. J Gt Lakes Res 43:127-131

Munis AM, Tijani M, Hassal M, Mattiuzzo G, Collins MK, Takeuchi Y (2018) Characterization of antibody interactions with the $\mathrm{G}$ protein of vesicular stomatitis virus Indiana strain and other vesiculovirus G proteins. J Virol 92: e00900-e00918

Neukirch M, Böttcher K, Bunnajjirakul S (1999) Isolation of a virus from koi with altered gills. Bull Eur Assoc Fish Pathol 19:221-224

Nishizawa T, Kinoshita S, Yoshimizu M (2005) An approach for genogrouping of Japanese isolates of aquabirnaviruses in a new genogroup, VII, based on the VP2/NS junction region. J Gen Virol 86:1973-1978

* Notredame C, Higgins DG, Heringa J (2000) T-Coffee: a novel method for fast and accurate multiple sequence alignment. J Mol Biol 302:205-217

NRC (National Research Council) (2011) Guide for the care and use of laboratory animals, $8^{\text {th }}$ edn. National Academies Press, Washington, DC
OIE (World Organization for Animal Health) (2019a) Aquatic animal health code 2019. www.oie.int/en/internationalstandard-setting/aquatic-code/access-online/ (accessed 4 December 2019)

OIE (World Organization for Animal Health) (2019b) Principles and methods of validation of diagnostic assays for infectious diseases. Chap 1.1.2. In: Manual of diagnostic tests for aquatic animals 2019. www.oie.int/internationalstandard-setting/aquatic-manual/access-online/ (accessed 4 December 2019)

OIE (World Organization for Animal Health) (2019c) Spring viraemia of carp. Chap 2.3.9. In: Manual of diagnostic tests for aquatic animals 2019. www.oie.int/internationalstandard-setting/aquatic-manual/access-online/ (accessed 4 December 2019)

OIE (World Organization for Animal Health) (2019d) Development and optimisation of nucleic acid detection assays. Chap 2.2.3. In: Manual of diagnostic tests for terrestrial animals 2019. www.oie.int/internationalstandard-setting/terrestrial-manual/access-online/ (accessed 4 December 2019)

*Padhi A, Verghese B (2008) Detecting positively selected codons in the glycoprotein of spring viraemia of carp virus (SVCV) isolates from the USA and China. J Fish Dis 31:785-791

*Padhi A, Verghese B (2012) Molecular evolutionary and epidemiological dynamics of a highly pathogenic fish rhabdovirus, the spring viremia of carp virus (SVCV). Vet Microbiol 156:54-63

* Phelps NBD, Armien AG, Mor SK, Goyal SM, Warg JV, Bhagyam R, Monahan T (2012) Spring viremia of carp virus in Minnehaha Creek, Minnesota. J Aquat Anim Health 24:232-237

Reichenheim ME (2004) Confidence intervals for the kappa statistic. Stata J 4:421-428

Roche S, Bressanelli S, Rey FA, Gaudin Y (2006) Crystal structure of the low-pH form of the vesicular stomatitis virus glycoprotein G. Science 313:187-191

* Roche S, Rey FA, Gaudin Y, Bressanelli S (2007) Structure of the prefusion form of the vesicular stomatitis virus glycoprotein G. Science 315:843-848

Rose J, Schubert M (1987) Rhabdovirus genomes and their products. In: Wagner R (ed) The rhabdoviruses. Plenum, New York, NY, p 129-166

* Salama MA, Hassanien AE, Mostafa A (2016) The prediction of virus mutation using neural networks and rough set techniques. EURASIP J Bioinform Syst Biol 2016:10 (eCollection 2016 Dec)

Sepahi A, Kraus A, Casadei E, Johnston CA and others (2019) Olfactory sensory neurons mediate ultrarapid antiviral immune responses in a TrkA-dependent manner. Proc Natl Acad Sci USA 116:12428-12436

Shao L, Xiao Y, He Z, Gao L (2016) An N-targeting real-time PCR strategy for the accurate detection of spring viremia of carp virus. J Virol Methods 229:27-34

Shchelkunov IS, Shchelkunova TI (1989) Rhabdovirus carpio in herbivorous fishes: isolation, pathology and comparative susceptibility of fishes. In: Ahne W, Kurstak E (eds) Viruses of lower vertebrates. Springer-Verlag, Berlin, p 333-348

Spearman C (1908) The method of right and wrong cases (constant stimuli) with Gauss's formulae. Br J Psychol 2: 227-242

Stone DM, Ahne W, Denham KL, Dixon PF and others (2003) Nucleotide sequence analysis of the glycoprotein gene of 
putative spring viraemia of carp virus and pike fry rhabdovirus isolates reveals four genogroups. Dis Aquat Org 53:203-210

Stone DM, Kerr RC, Hughes M, Radford AD, Darby AC (2013) Characterisation of the genomes of four putative vesiculoviruses: tench rhabdovirus, grass carp rhabdovirus, perch rhabdovirus and eel rhabdovirus European X. Arch Virol 158:2371-2377

Sulimanovic D (1973) Immunity of carp to Rhabdovirus carpio and determination of antibodies by indirect hemagglutination. Vet Arh 43:153-161

Teng Y, Liu H, Lv JQ, Fan WH, Zhang QY, Qin QW (2007) Characterization of complete genome sequence of the spring viremia of carp virus isolated from common carp (Cyprinus carpio) in China. Arch Virol 152:1457-1465

Thompson JD, Higgins DG, Gibson TJ (1994) CLUSTAL W: improving the sensitivity of progressive multiple sequence alignment through sequence weighting, position specific gap penalties and weight matrix choice. Nucleic Acids Res 22:4673-4680

Vandepol SB, Lefrancois L, Holland JJ (1986) Sequences of the major antibody binding epitopes of the Indiana serotype of vesicular stomatitis virus. Virology 148: 312-325

Wang Y, Zhang H, Lu Y, Wang F, Liu L, Liu J, Liu X (2017) Comparative transcriptome analysis of zebrafish (Danio rerio) brain and spleen infected with spring viremia of carp virus (SVCV). Fish Shellfish Immunol 69:35-45

Warg JV, Dikkeboom AL, Goodwin AE, Snekvik K, Whitney

Editorial responsibility: Catherine Collins,

Jouy-en-Josas, France
J (2007) Comparison of multiple genes of spring viremia of carp viruses isolated in the United States. Virus Genes 35:87-95

Way K, Denham KL, Dixon PF, Longshaw CB, Sheppard AM, Stone DM (2003) Atypical spring viraemia of carp virus (SVCV) isolated from carp imported into the UK: evidence from phylogenetic analysis of partial gene sequences for a number of distinct sub-groups of SVCV. https://www.cefas.co.uk/publications/posters/30563web. pdf

* Winton J, Batts W, deKinkelin P, LeBerre M, Bremont M, Fijan N (2010) Current lineages of the epithelioma papulosum cyprinid (EPC) cell line are contaminated with fathead minnow, Pimephales promelas cells. J Fish Dis 33: 701-704

Wolf K (1988) Fish viruses and fish viral diseases. Cornell University Press, Ithaca, NY

Y Yue Z, Teng Y, Liang C, Xie X and others (2008) Development of a sensitive and quantitative assay for spring viremia of carp virus based on real-time RT-PCR. J Virol Methods 152:43-48

Khang NZ, Zhang LF, Jiang YN, Zhang T, Xia C (2009) Molecular analysis of spring viraemia of carp virus in China: a fatal aquatic viral disease that might spread in east Asian [sic]. PLOS ONE 4:e6337

* Zhu B, Zhang C, Yang B, Guo ZR, Zheng YY, Gong YM, Wang GX (2019) Preliminary screening and immunogenicity analysis of antigenic epitopes of spring viremia of carp virus. Fish Shellfish Immunol 94:833-841

Submitted: June 1, 2020; Accepted: November 13, 2020

Proofs received from author(s): February 12, 2021 